\title{
Leaching of viruses and other microorganisms naturally occurring in pig slurry to tile drains on a well-structured loamy field in Denmark
}

\author{
Jesper S. Krog ${ }^{1,2}$ • Anita Forslund ${ }^{1,3}$ • Lars E. Larsen ${ }^{1}$. Anders Dalsgaard ${ }^{3}$. \\ Jeanne Kjaer ${ }^{4}$ Preben Olsen ${ }^{5}$ Anna Charlotte Schultz ${ }^{2}$
}

Received: 15 May 2016/Accepted: 29 December 2016/Published online: 3 February 2017

(C) The Author(s) 2017. This article is published with open access at Springerlink.com

\begin{abstract}
The amount of animal manure used in modern agriculture is increasing due to the increase in global animal production. Pig slurry is known to contain zoonotic bacteria such as E. coli, Salmonella spp. and Campylobacter spp., and viruses such as hepatitis $E$ virus and group A rotavirus. Coliform bacteria, present in manure, have previously been shown to leach into tile drains. This poses a potential threat to aquatic environments and may also influence the quality of drinking water. As knowledge is especially scarce about the fate of viruses when applied to fields in natural settings, this project sets out to investigate the leaching potential of six different microorganisms: E. coli and Enterococcus spp. (detected by colony assay), somatic coliphages (using plaque assays), and hepatitis $\mathrm{E}$ virus, porcine circovirus type 2, and group A rotavirus (by real-time polymerase chain reaction). All six microorganisms leached through the soil entering the tile drains situated at 1-m depth the first day following pig
\end{abstract}

Published in the special issue "Hydrogeology and Human Health"

Jesper S. Krog and Anita Forslund contributed equally to this work

Anita Forslund

anfor@vet.dtu.dk

1 National Veterinary Institute, Technical University of Denmark, Bülowsvej 27, DK-1870 Frederiksberg, Denmark

2 Division of Microbiology and Production, National Food Institute, Technical University of Denmark, DK-2860 Søborg, Denmark

3 Department of Veterinary Disease Biology, Faculty of Health and Medical Sciences, University of Copenhagen, DK-1870 Frederiksberg, Denmark

4 Department of Geochemistry, Geological Survey of Denmark and Greenland (GEUS), DK-1350, Copenhagen, Denmark

5 Department of Agroecology, Aarhus University, DK-8830 Tjele, Denmark slurry application. The leaching pattern of group A rotavirus differed substantially from the pattern for somatic coliphages, which are otherwise used as indicators for virus contamination. Furthermore, group A rotavirus was detected in monitoring wells at 3.5-m depth up to 2 months after pig slurry application. The detection of viral genomic material in drainage water and shallow groundwater signifies a potential hazard to human health that needs to be investigated further, as water reservoirs used for recreational use and drinking water are potentially contaminated with zoonotic pathogens.

Keywords Health · Pathogen - Solute transport ·

Agriculture · Groundwater monitoring

\section{Introduction}

While the threat of contamination by nutrients leaching from manure-treated fields is well recognized, the threat by leaching of zoonotic pathogens from the manure has received much less attention. Livestock manure is commonly used in modern agriculture as fertilizer. Millions of tons of manure are excreted from livestock and applied to farmland annually. In the United States, livestock excrete approximately 500 million tons of manure annually (USEPA 2003). In Europe, the entire manure production is estimated to be 1.4 billion tons per year (Foged et al. 2011). An estimated 26 million tons of livestock manure was spread on Danish farmland in 2011 (Danish Agriculture and Food Council 2012).

Livestock manure contains nutrients and organic matter used to enhance soil properties and thus crop production, but may also contain a variety of zoonotic pathogens (Cole et al. 1998; Sobsey et al. 2001; Ziemer et al. 2010). Animal pathogens with potential negative impact on human health (zoonosis) include, rotavirus group A (RV-A), hepatitis E virus 
(HEV), Salmonella spp., E. coli O157:H7 and Cryptosporidium parvum (Ziemer et al. 2010). With the emergence of avian and swine influenza, there has been an increased surveillance and focus on zoonotic viruses. The transmission of viruses between mammals through environmental reservoirs is, however, poorly understood. In the non-industrialized part of the world, hepatic viruses such as hepatitis A virus (HAV) and HEV cause many waterborne epidemics (Naik et al. 1992). In the western world, HEV was previously regarded as a travelrelated illness (Hsieh et al. 1999); however, HEV genotype 3 has since been discovered in pigs worldwide (Meng et al. 1997), and is now considered endemic in pigs in many European countries and North America and as the main reservoir for locally acquired HEV. The prevalence of anti-HEV antibodies in humans ranges between 2 and 53\% (Bouwknegt et al. 2008; Christensen et al. 2008; Mansuy et al. 2011; Purcell and Emerson 2008). Detection of HEV in wastewater from urban areas has been reported in European and North American cities (Clemente-Casares et al. 2003), indicating that $\mathrm{HEV}$ may be present in the water environment. Another virus with zoonotic potential is RV-A. RV-A mainly infects younger animals and children, and is the primary cause of hospitalization of children due to gastroenteritis (Martella et al. 2010). RVA has proved to be very persistent in pig slurry storage tanks, with a reduction in infectivity of only one log-unit found after 6 months (Pesaro et al. 1995).

Enteric viruses and bacteria have been isolated from and linked to disease outbreaks associated with contaminated drinking-water sources, recreational waters and rivers exposed to fecal contaminated water (Croci et al. 2008; Fong and Lipp 2005; Harris et al. 2003; Lipp and Rose 1997; Reynolds et al. 2008; Sair et al. 2002). Therefore, detailed knowledge on the transport of microorganisms through soil is important when measures to protect groundwater reservoirs from contamination are to be established. E. coli O157:H7 and Campylobacter jejuni originating from manure resulted in a large waterborne disease outbreak when people in Walkerton, Canada, consumed contaminated drinking water (Hrudey et al. 2002). The most plausible route of contamination of the city's water reservoir was rapid horizontal transport in fractured bedrock. Similarly, drinking well water in a restaurant in Wisconsin (USA) was associated with illness caused by NoV (Borchardt et al. 2011). Zoonotic viruses such as HEV originating from pig slurry could pose a similar public health risk if transported to water bodies, including drinking water reservoirs; therefore, it is necessary to determine the travel distances and survival times of viruses in soils and use such data for risk assessments and the establishment of measures to manage contamination of drinking water sources and public health protection (Azadpour-Keeley et al. 2003).

Macropores (earthworm channels, cracks, fractures, old root canals) are present in structured loamy and clayey soils (Jacobsen and Kjaer 2007). Preferential flow through macropores can take place when the soil is nearly saturated and at some point above the water-entry pressure of the soil. Differences in the hydraulic conductivity between macropores and soil matrix can then cause a non-equilibrated flow, where the water in the macropores moves faster than the wetting front in the matrix (Jarvis 2007).

Since water-dispersible colloids have surface charge and high specific surface area, they can effectively adsorb weakly soluble, strongly sorbing contaminants (Kretzschmar et al. 1999; de Jonge et al. 2004). Thereby colloids can convey adsorbed compounds such as phosphorus (de Jonge et al. 2004; Norgaard et al. 2012) and pesticides (Flury 1996; Gjettermann et al. 2009; Kjær et al. 2011) and pathogens (Bradford et al. 2013), from the surface to deeper soil layers through preferential pathways. Transport of microorganisms and colloids through soil depends on soil type and texture, the presence of macropores, precipitation and antecedent moisture content of the soil, manure constituents and chemical composition as well as the size and surface properties of the colloids and microorganisms. Preferential water movement is probably the primary route for rapid transport of microorganisms through soil and thereby has a major impact on the microbial leaching (Abu-Ashour et al. 1994; Forslund et al. 2011a; Guber et al. 2007; Jarvis 2007; Nicosia et al. 2001; Walshe et al. 2010). Increased transport of microorganisms has been observed in soil with high clay content because water flow in clay-rich soils is usually concentrated in the fractures (AbuAbu-Ashou et al. 1998; Beven and Germann 1982). The ability of different sized microorganisms e.g. viruses, bacteria or protozoan parasites, to travel fast through soil fractures has been recognized (Bradford et al. 2013). The ability of the microorganisms to survive in the soil environment depends on factors such as type of microorganism, temperature, $\mathrm{pH}$, moisture and composition of the indigenous microflora (Azadpour-Keeley et al. 2003; Vinten et al. 2002). Field experiments are an advantage compared to simulated laboratory experiments with soil cores. In field experiments, microorganisms are exposed to natural weather conditions, e.g. fluctuating temperatures and humidity, wind and precipitation influencing the transport and survival of microorganisms in soil. Further, both the variation in soil structure and the spatial distribution of connective preferential flow paths are intact in field experiments, while soil cores only represent a small fraction of the field and excavation could affect the soil architecture. Conversely, the enhanced level of complexity in field experiments also makes it difficult to estimate the dominant processes involved in the microbial migration (Bradford et al. 2013).

Field studies have shown that transport of slurry constituents through soil to tile drains is possible and can occur shortly after slurry application (Evans and Owens 1972; Fleming and Bradshaw 1992; Kjær et al. 2007; McLellan et al. 1993; Naden et al. 2010). Field studies have mainly focused on fecal indicator organisms, e.g. E. coli and enterococci as well as 
bacteriophages used as model organisms for viruses (DeBorde et al. 1998; Oliver et al. 2005; Pappas et al. 2008; Schijven et al. 1999), while studies on waste-associated human viruses, providing valuable information on the transport of these pathogens through the vadose zone (Borchardt et al. 2011; Jansons et al. 1989), are limited. Due to the potential contamination associated with applying zoonotic viruses in environmental studies, bacteriophages have been used as a model for leaching of zoonotic viruses through soil (Forslund et al. 2011b; Havelaar 1991; Hijnen et al. 2005; Mesquita and Emelko 2012).

Many countries assess the microbiological quality of water based on bacterial indicators such as enumeration of enterococci and fecal coliform and total coliform bacteria, but such bacteria are often poor indicators of viruses (Gibson and Schwab 2011; Jiang et al. 2001). Enteric viruses have been recognized as the causative agents in gastroenteritis outbreaks caused by water that have met bacteriological standards (Bosch 1998). Over 100 types of pathogenic viruses have been described to occur in water that has been contaminated with fecal material (Pillai 2006); therefore, the use of nonpathogenic viral indicators of fecal contamination, e.g. coliphages, is an important tool in public health studies, when tracing sources of groundwater contamination (Snowdon et al. 1989). With the vast amounts of livestock manure spread on agricultural fields worldwide, there is a particular need for studies that are designed to measure the leaching of zoonotic viruses normally present in animal slurry. There are currently no regulations in place on national or European Union level regarding limiting the content of microorganisms in manure allowed to be applied to fields. The regulations regarding application of manure that are enforced in Denmark are primarily to prevent bothersome odor to nearby residential areas and to limit field run-off into nearby water bodies.

The main objective of the present study was to assess the potential of viruses from different families, such as HEV and RV-A, leaching into the aquatic environment when manure from an typical Danish pig producing facility is applied to a field under conditions used by Danish farmers. In addition, the purpose was to compare the leaching capabilities of E. coli, Enterococcus spp., somatic coliphages, HEV, PCV2 and RV$\mathrm{A}$, and lastly, to evaluate if somatic coliphages are appropriate model organisms for viruses originating from pigs under natural field conditions.

\section{Materials and methods}

\section{Test field site}

The experimental site was located at Silstrup, south of Thisted in northwestern Jutland, Denmark ( $56^{\circ} 56^{\prime} \mathrm{N}, 8^{\circ} 39^{\prime} \mathrm{E}$ ). The field is a part of the Danish Pesticide Leaching Assessment
Program (Lindhardt et al. 2001). The field was $17,100 \mathrm{~m}^{2}$ $(1.71 \mathrm{ha})$ and the terrain sloped gently $1-2^{\circ}$. The site was located on a glacial moraine of Late Weichselian age and has been exposed to weathering, erosion, leaching, and other geomorphologic processes for about 16,000 years (Lindhardt et al. 2001). The soil was a sandy clay loam (14.6\% clay, $11.6 \%$ silt, $67.7 \%$ sand and $4.1 \%$ organic matter) with pH 7.1 and a porosity of $0.42 \mathrm{~cm}^{3} \mathrm{~cm}^{-3}$ (Lindhardt et al. 2001). The soil was prone to preferential transport as it is heavily fractured and bioturbated with 400 biopores per $\mathrm{m}^{2}$ found $0.6 \mathrm{~m}$ below ground surface (bgs). These observations was done in a $5 \mathrm{~m}$ deep $10 \times 10 \mathrm{~m}$ test pit excavated nearby the north eastern corner of the field, following the methodology of Klint and Gravesen (1999). These observations were in line with previous studies conducted in other similar soil types in Denmark (Ernstsen 2004). The drainage system in the field consisted of five parallel field drains running from south to the north (Fig. 1). The five drains were connected to a transverse collector drain from which drainage water samples were collected. The tile drains were installed at an average depth of $1.1 \mathrm{~m}$ and an interspacing of approximately $17-18 \mathrm{~m}$. Conventional agriculture with ploughing depths of around $22-24 \mathrm{~cm}$ had been practiced at the site during the previous 27 years and red fescue (Festuca ruba L.) was grown on the field during the study period. The slurry was surface applied with trailer hoses on 5 October 2011. There was no tillage in connection with the application of the slurry, but after desiccation of the grass with glyphosate on 10 September 2012, the field was ploughed to $24 \mathrm{~cm}$ depth, i.e. nearly a year after the use of slurry.

The field was encircled by a grass-covered buffer zone being $18 \mathrm{~m}$ wide to the north and west, and $10 \mathrm{~m}$ to the east, and to the south, a 7-m grass-covered buffer zone was supplemented by a 3-m paved road. The site had equipment installed to record water-table depth, the minimum and maximum air temperature, and soil temperature $-30 \mathrm{~cm}$ below ground surface (bgs) - on an hourly basis. Soil temperature was measured hourly by means of a platinum resistance thermometer (Pt-100) at two locations (Fig. 1). Precipitation was measured at the site using a tipping bucket rain gauge system.

\section{Sampling of pig slurry and drainage water}

The pig (Sus scrofa domesticus) slurry was supplied by a local farmer. On the 5 October 2011, the pig slurry was homogenized in the storage tank for approximately $1 \mathrm{~h}$, using a slurry agitator (Kimidan Multimixer, Denmark). A total of 49 tons ( 29 tons $\mathrm{ha}^{-1}$ ) of homogenized pig slurry was applied in bands on the soil surface by trailer hosing. The pig slurry was tested for the presence of somatic- and F-RNA coliphages, E. coli and Enterococcus spp., Salmonella spp. and swine influenza virus (SIV), porcine parvovirus (PPV), HEV, RV-A, and PCV2 as described below. Initial analysis showed that 
Fig. 1 Schematic drawing of the test site located near Silstrup, Denmark

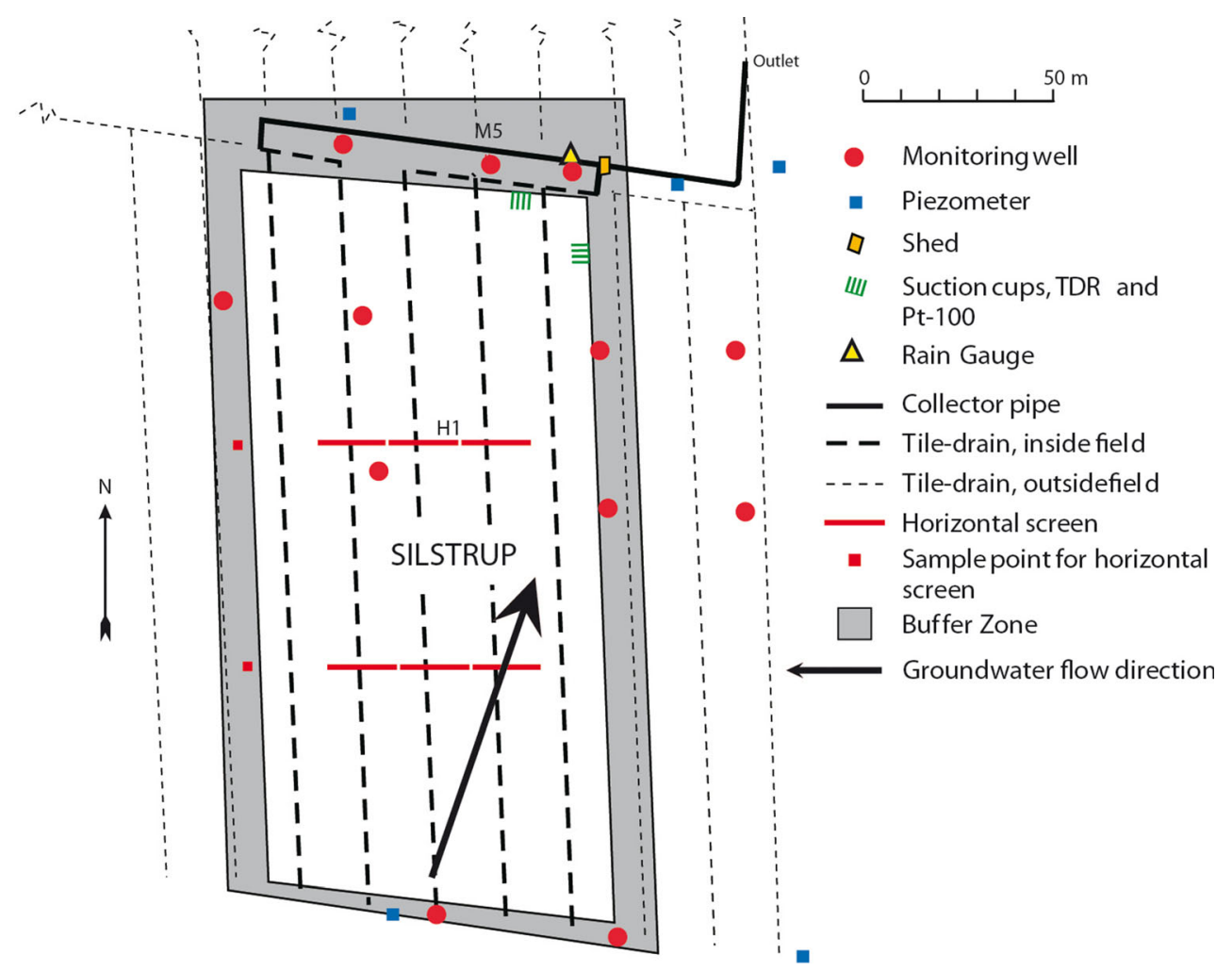

E. coli, Enterococcus spp., somatic coliphages, HEV, PCV2 and RV-A were present in the pig slurry and they were therefore all selected for analysis in the leaching study (Table 1). Porcine circovirus type 2 (PCV2) was included as this virus is ubiquitous in swineherds and highly persistent in the farm environment (Kristensen et al. 2013). Drainage water was sampled flow-proportionally (Plauborg et al. 2003; ISCO 6700 sampler, Teledyne Isco Inc., US). For weekly samples, the microbiological analysis was performed on pooled water samples containing all the subsamples collected during the past week to obtain a weighted average concentration. Following the onset of heavy rainfall events, drainage water was sampled flow-proportionally for approximately 1 day. To obtain weighted average concentrations for each heavy rain event, the microbiological analysis was performed on pooled water samples containing all the subsamples collected during the heavy rain event. The heavy rain events were defined as events causing the water level and accumulated flow rate within the preceding 12-h period to exceed predefined levels that depended on the month of the year. The pre-defined level for triggering of sampling depended on the season of the year. An amount of 200-ml subsamples was taken for every 3,000 L of drainage flow during the winter season (September-May) and for every 1,500 L during the summer period (JuneAugust; Plauborg et al. 2003); additionally, groundwater samples were collected monthly from both the vertical well M5 and the horizontal monitoring well H1 (Fig. 1). The vertical monitoring well, installed in the surrounding buffer zone, consists of four 1-m screens, covering the upper approx. $4 \mathrm{~m}$ of the saturated zone. The screens were made from highdensity polyethylene (HDPE) with an outside diameter of $63 \mathrm{~mm}$ and a wall thickness of $5.8 \mathrm{~mm}$. Samples were collected from the upper-most filter located $1.5-2.5 \mathrm{~m}$ bgs. In addition, horizontal monitoring wells were installed $3.5 \mathrm{~m}$ beneath the test sites. The horizontal screens were installed by drilling from the buffer zone on the one side of the field to the buffer zone on the opposite side, without causing any disturbance to the topsoil within the cultivated area. Each horizontal monitoring well consists of three 18-m screens providing integrated water samples characterizing groundwater quality just beneath the test site (Fig. 1). Samples were collected from the middle filter of the three filters (Fig. 1). The horizontal screens were made of HDPE with an outer diameter of $125 \mathrm{~mm}$ and a wall thickness of $5.8 \mathrm{~mm}$. Three individual screens were installed in each borehole separated by 1-m bentonite seals. An inner pipe (outer diameter of $63 \mathrm{~mm}$ ), used for outlet tubes from each of the three screens, transversed the entire installation (Lindhardt et al. 2001). The day before a sampling, the wells were purged to ensure that fresh groundwater was sampled. Additional information about sampling methods and monitoring design is available in Lindhardt et al. (2001) and Rosenbom et al. (2015).

The collection of water samples was conducted from 22 September until 5 January 2012. All samples were kept in a cooling box and transported to the laboratory where analysis for somatic coliphages and viable indicator bacteria were 


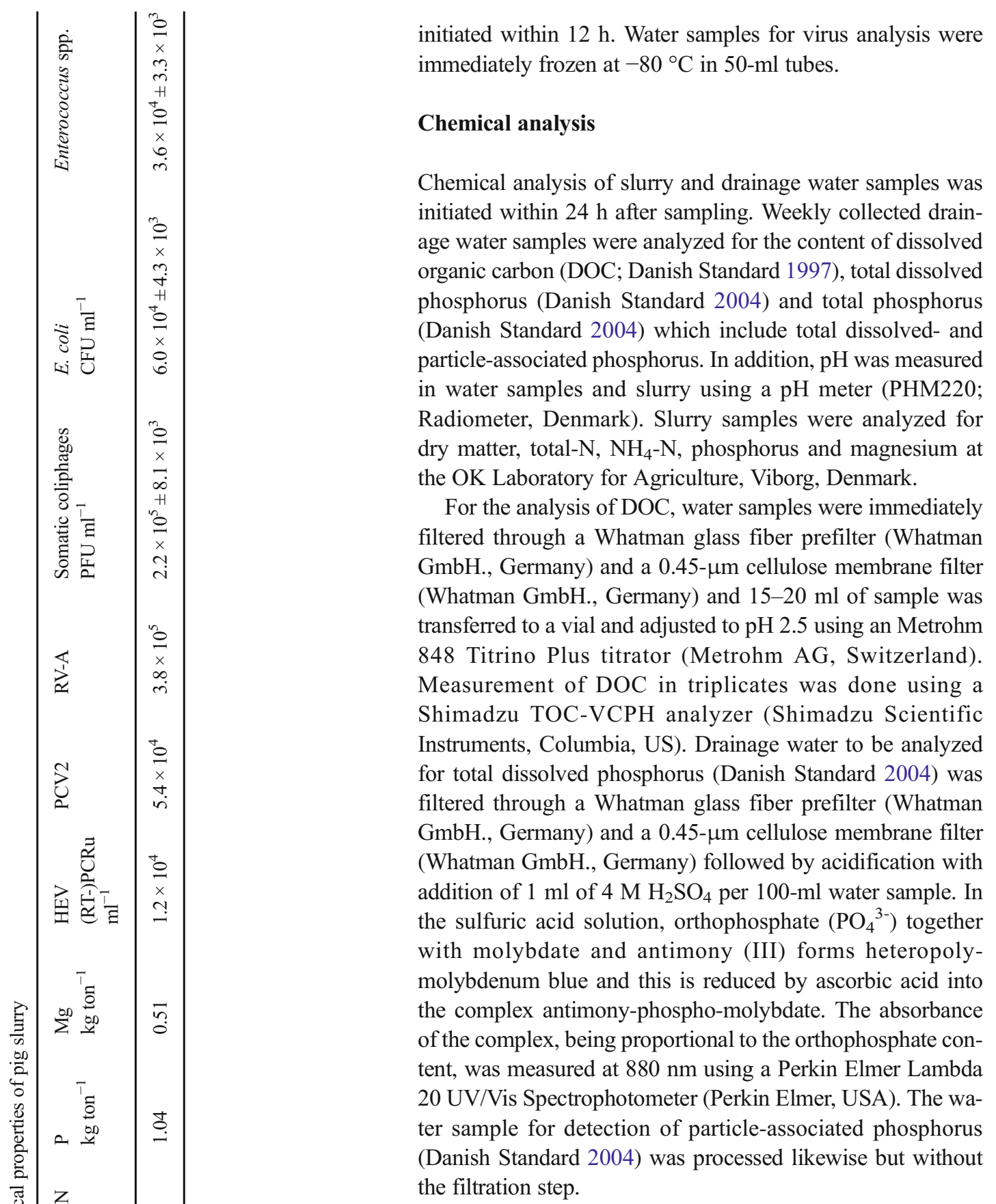

Microbial analysis

Fecal bacterial indicators

In both slurry and water samples, the fecal indicator organisms E. coli and Enterococcus spp. were enumerated by direct plating in triplicate on selective agar plates with a detection limit of $1 \mathrm{CFU} \mathrm{ml}{ }^{-1}$. Water and slurry samples were 10-fold diluted in Maximum Recovery Diluent (Oxoid, Hampshire, United Kingdom). Concentration of $E$. coli was determined on Brilliance E. coli/coliform Selective Agar (Oxoid), where colonies appear as typical indigo blue colonies after incubation at 
$37{ }^{\circ} \mathrm{C}$ for $21 \pm 3 \mathrm{~h}$ (Wohlsen 2011; Wuton et al. 2009). The concentration of Enterococcus spp. was determined as the number of typical red-maroon colonies on Slanetz and Bartley medium (Oxoid) following incubation at $44{ }^{\circ} \mathrm{C}$ for $48 \pm 4 \mathrm{~h}$ (Danish Standard 1999). Since the concentration of both E. coli and Enterococcus spp. were determined from triplicate diluted samples, the average concentration reported can be less than $1 \mathrm{CFU} \mathrm{ml}^{-1}$.

\section{Somatic coliphages}

Somatic coliphages is a group of bacteriophages with the ability of infecting E. coli via the cell wall and belongs to four different families (Lee 2009). Somatic coliphages were analyzed in triplicates with a detection limit of $1 \mathrm{PFU} \mathrm{m}{ }^{-1}$ by plaque assay according to ISO 10705-2 (ISO 2001). The acceptable range of error of the plaque assay is $\pm 20 \%$ (Chu et al. 2001). Briefly, slurry and water samples were 10 -fold serially diluted in Maximum Recovery Diluent (Oxoid) and enumerated by the double-agar layer method. The host strain $E$. coli ATCC 13706 was grown in nutrient broth (Oxoid) at $37^{\circ} \mathrm{C}$ for $4 \mathrm{~h}$. From the 10-fold diluted samples, $1 \mathrm{ml}$ was mixed with 1$\mathrm{ml}$ broth culture of the host strain and 3-ml soft agar consisting of 70\% blood agar base (Oxoid) and 30\% nutrient broth (Oxoid). The mixture was gently mixed and spread on a well-dried blood agar base plate (Oxoid). Plates were incubated at $37{ }^{\circ} \mathrm{C}$ for $18 \mathrm{~h}$ and clear zones (plaques; PFU) were counted. Slurry was filtered through $0.45-\mu \mathrm{m}$ pore size filters (Sartorius, Goettingen, Germany) before mixed with the soft agar when high bacterial background flora was expected. Concentration of somatic coliphages was determined from triplicate diluted samples and the average concentration reported can be less than $1 \mathrm{PFU} \mathrm{ml}{ }^{-1}$.

\section{Viruses}

Prior to precipitation of viruses, the $\mathrm{pH}$ of slurry and water samples was adjusted to $\mathrm{pH} 7$ using $\mathrm{NaOH}$ and then clarified from debris by centrifugation at $4,000 \mathrm{rpm}$ for $30 \mathrm{~min}$ at $4{ }^{\circ} \mathrm{C}$. To precipitate viruses; $40 \mathrm{ml}$ of the supernatant was transferred to tubes containing $0.7 \mathrm{~g} \mathrm{NaCl}$ (Sigma-Aldrich, Brøndby, Denmark) and 3.2-g polyethylene glycol (PEG 8000 Fischer Scientific, Slangerup, Denmark). The samples were placed on a shaking bed over night at $4{ }^{\circ} \mathrm{C}$ followed by centrifugation at $10,000 \mathrm{rpm}$ for $90 \mathrm{~min}$ at $4{ }^{\circ} \mathrm{C}$. The supernatant was discarded and viral nucleic acid was purified from the pellet using NucliSENSE reagents and the miniMag platform (bioMérieux, Herlev, Denmark) according to the manufacturer's protocol. The nucleic acid was eluted in $100-\mu 1$ RNase free water. The efficiency of viral concentration and viral nucleic acid extraction inherent to the procedure for virus recovery were quality assessed using an internal process control (IPC). For this mengovirus $\left(\mathrm{MC}_{0}\right.$; strain ATCC VR-1957;
Costafreda et al. 2006), approximately $10^{4}$ plaque forming units was added to each water sample before the initial step of viral precipitation, and to a non-matrix sample before nucleic acid extraction. After extraction of samples seeded with the $\mathrm{MC}_{0}$, the $\mathrm{Ct}$ (Cycle threshold) value of the water samples was compared to the $\mathrm{Ct}$ value of the non-matrix sample used in the extraction series and to a standard curve obtained by endpoint dilution with one real-time reverse transcriptase polymerase chain reaction (rt-RT-PCR) unit defined as the lowest possible detectable dilution. The difference $(\Delta \mathrm{Ct})$ was used to determine the extraction efficiency, using $100 \mathrm{e}^{-0.6978 \Delta \mathrm{Ct}}$ (Costafreda et al. 2006); as negative process control, clean water was added in a parallel sample.

For each rt-PCR run, a positive amplification control (PAC; nucleic acid extract from feces samples previously tested positive for the three target viruses, PCV-2, HEV and RV-A) and a no template control (NTC) was included. Samples and controls were analyzed in duplicates. The requirement for successful extraction and rt-PCR run was that the negative controls tested negative and that the individual positive controls met the set $\mathrm{Ct}$ requirements established under the validation of the assays. The process control $\mathrm{MC}_{0}$ were detected using the RNA Ultrasense One-Step qRT-PCR System (Invitrogen, Nærum, Denmark) and the primers, probe and reaction conditions described by Pintó et al. (2009). HEV was detected by a one-step rt-RT-PCR assay using primer probe energy transfer (PriProET) chemistry (Breum et al. 2010) but modified to a lower final primer and probe concentration of $500 \mathrm{nM}$ for HEV2-R and HEV2-P and $100 \mathrm{nM}$ for HEV2-F. The target for the assay is the ORF2-encoded capsid protein, whereas the standard curve was prepared from plasmids containing the target gene of the assay. The amplification efficiency of the assay was $88 \%$ with a slope of -3.64 . The detection of PCV2 was accomplished with the assay which targets ORF1 and utilizes the PriProET chemistry (Hjulsager et al. 2009). The standard curve used to assess viral load was made by spiking negative fecal samples with plasmid, while the amplification efficiency of the assay was $82 \%$ and the slope -3.86 . For detection of RV-A, the primer and probes used in the assay along as well as the PCR cycling conditions were adopted from Pang et al. (2004) and the assay was modified by the use of the RNA UltraSense One-Step Quantitative RT-PCR System (Invitrogen) and rt-RT-PCR analysis was performed on the Rotorgene Q real time PCR cycler (QIAGEN, Hilden, Germany). The primers and probe targets the NSP3 segment. Homologous sequences of the NSP3 target region are present in bovine, simian, porcine and human derived RV-A viruses (Pang et al. 2004). The standard curve was made from a serial dilution of RNA extracted from RV-A grown in the MA104 cell line and the amplification efficiency of the assay was $92 \%$ and the slope -3.54 . The standard curves were not used for absolute quantitation but to compare concentrations of each microorganism separately. Based on the dilution series made 
for the standard curve, a detection limit at $\mathrm{Ct} 38$ for HEV and PCV2 and 40 for RV-A was applied. The amount of detected target genomes in (RT)-PCR units (u) were measured by interpolation of the detected Ct-values of the respective viruses to their corresponding standard curves, with one unit defined as the lowest possible detectable dilution. In this study, no comparison was done on the exact number of viruses detected by the different assays; instead the (RT-)PCRu of each virus found in the drainage water was normalized against the (RT-)PCRu detected in the applied slurry. These are comparable as they are detected by the same assay and corrected against the same PCR controls in the Rotorgene software. These normalized concentrations of the viruses were then used in relation to leaching pattern, recovery and log-reduction in depth; a similar approach was applied to the other microorganisms.

\section{Data analysis and statistical methods}

Calculation of concentration and standard deviation of replicate samples for E. coli, Enterococcus spp. and somatic coliphages was done according to Niemela (1983). Due to the limited drainage runoff available, further reduction of the detection limit, thereby yielding higher colony counts and reducing uncertainty of data, was therefore not possible (Emelko et al. 2008).

The removal rate $\lambda$ (unit: $\log _{10} \mathrm{~m}^{-1}$ ) which defines the amount of microorganisms removed by passing through $1 \mathrm{~m}$ of soil was calculated using Eq. (1). The leaching of all microorganisms was normalized with the initial concentration detected in pig slurry $\left(C_{0}\right)$. The depth $(d)$ was set to the location of the tile drain, i.e. $1.1 \mathrm{~m}$ bgs, and the removal rate was calculated based on the highest concentration $\left(C_{\max }\right)$ recorded in the event samples as proposed by Pang et al. (2009).

$\lambda=-\frac{\log _{10}\left(\frac{C_{\max }}{C_{0}}\right)}{d}$

Recovery of microorganisms from pig slurry was calculated in three different ways, based on the maximum concentration detected in drainage water samples $\left(C_{\max }\right)$, in all event samples - i.e. where the amount of microorganisms found in each event sample was summed, and all weekly samples, i.e. total amount of microorganisms detected in all weekly samples collected during the study period.

The statistical analysis was performed on log-transformed normalized data by a permutation test with the main effect on leaching differences of microorganisms and on days of sampling. The simulated P-values for the corresponding permutation tests on F-test values were calculated using $\mathrm{R}$ statistical software suite version 3.0.0 (R Core Team 2013) with the $1 \mathrm{mPerm}$ package version 1.1.2 (Wheeler 2010). The significance level was set at $P=0.05$. Pearson product-moment correlation coefficients were derived to assess the association between microbiological and environmental variables such as DOC, total dissolved- and particle-associated phosphorus. The Pearson coefficient was calculated using Excel version 15.

\section{Results}

\section{Climate conditions}

In the study period, running from 5 October 2011 to 5 January 2012, the total precipitation amounted to $286 \mathrm{~mm}$. During October, drainage runoff only occurred during four precipitation events. The month of November was relatively dry with 49.5- $\mathrm{mm}$ precipitation compared to $108 \mathrm{~mm}$ for the average of November recorded in 1961-1990 on site. This resulted in an entire month devoid of drainage runoff. At the end of November and start of December heavier rain resumed drainage runoff. The experiment ended in January with large amounts of precipitation and drainage runoff (Fig. 2e). The air temperature in the study period varied between -2.6 and $15.4^{\circ} \mathrm{C}$ and was relatively high for the season with the three primary months having only a total of three subzero days (Fig. 2f). Soil temperature at $30 \mathrm{~cm}$ bgs was below $15^{\circ} \mathrm{C}$ for the entirety of the study. Prior to the study period, the site was monitored for 2 weeks. Because precipitation was scarce, insufficient drainage runoff limited microorganism analysis.

\section{Leaching of microorganisms}

Initial analysis of water, collected from drains (bacteria and somatic coliphages) 14 days prior to pig slurry application, and groundwater monitoring wells (bacteria, somatic coliphages and viruses) 1 day prior to pig slurry application, showed no presence of E. coli, Enterococcus spp., and somatic coliphages, nor of the viruses HEV, PCV2 and RV-A (Fig. 2c,d). The leaching of microorganisms is illustrated in the breakthrough curve (BTC) during the study period with the concentration detected in drainage water normalized against the initial concentration found in the pig slurry (Fig. 2). The initial breakthrough and relative concentrations of microorganisms is shown for weekly and event samples collected from the drains (Fig. 2b,c).

E. coli and Enterococcus spp. was detected in the first of three event samples caused by intensive rainfall during the first week (Fig. 2c). This rain event happened on the day after the pig slurry was applied and the concentration of E. coli and Enterococcus spp. in drainage water was 30 C F U m l $1^{-1} \pm 3.6 \quad \mathrm{CF} \mathrm{U}^{-1}$ a n d $27 \mathrm{CFU} \mathrm{ml}{ }^{-1} \pm 3.4 \mathrm{CFU} \mathrm{ml}^{-1}$, respectively. Enterococcus spp. was detected again in the event samples collected 

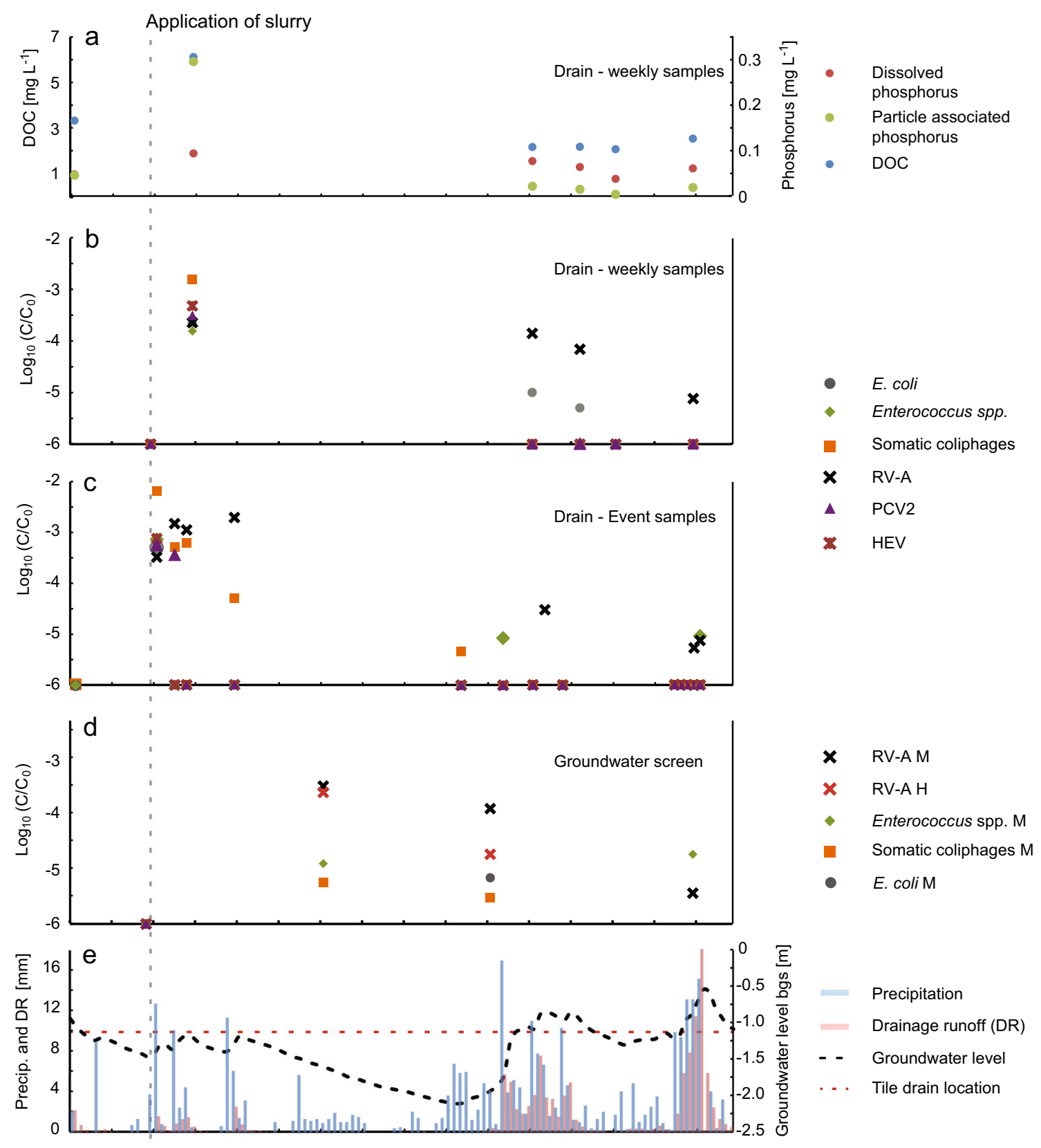

- E. coli

- Enterococcus spp.

- Somatic coliphages

$\times \quad$ RV-A

- PCV2

* HEV

- E. coli M

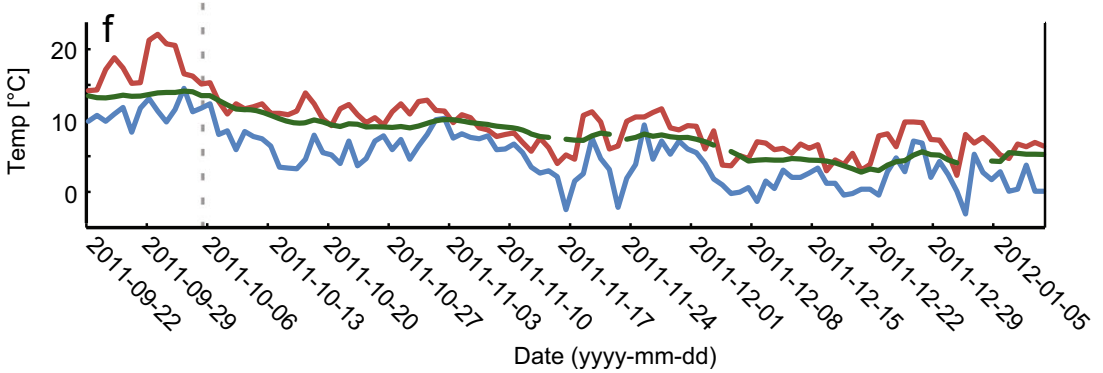

Max Air Temp
Min Air Temp
$\begin{aligned} & \text { Soil temp at } 1 \\ & \mathrm{~m} \text { bgs }\end{aligned}$

Fig. 2 Meteorological conditions and breakthrough curves for microorganisms and chemical constituents in drainage water in tile drains: a leaching of phosphorus and DOC; $\mathbf{b}$ breakthrough curves of the assayed microorganisms in the weekly drainage water samples; $\mathbf{c}$ the presence of microorganisms in tile drain at heavy rain events; $\mathbf{d}$ water samples collected monthly from both the vertical monitoring (M) and horizontal $(\mathrm{H})$ well and microorganisms shown on the $\mathrm{x}$-axis correspond to microorganisms below detection limit; e precipitation and drainage runoff (DR) together with the water-table depth; $\mathbf{f}$ temperature variation in air and soil. All samples below detection limit were set to -6 $\log$ units 
59 days (3 December 2011) and 92 days (5 January 2012) after application of pig slurry. These event samples were both collected during heavy rainfall (16.8 and $15 \mathrm{~mm} \mathrm{day}^{-1}$, respectively) with a concentration of $0.3 \mathrm{CFU} \mathrm{ml}^{-1} \pm 0.3 \mathrm{CFU} \mathrm{ml}{ }^{-1}$, essentially at the detection limit of the assay. E. coli and Enterococcus spp. was also found in the first weekly sample with a mean concentration of $13.5 \mathrm{CFU} \mathrm{ml}^{-1} \pm 2.4 \mathrm{CFU} \mathrm{ml}^{-1}$ and 5.7 CFU ml $\mathrm{Cl}^{-1} \pm 1.6 \mathrm{CFU} \mathrm{ml}^{-1}$, respectively (Fig. 2b). In the second and third weekly sample collected during the first and second week of December, E. coli was detected and the concentrations decreased to $0.6 \mathrm{CFU} \mathrm{ml^{-1 } \pm}$ $0.4 \mathrm{CFU} \mathrm{ml}^{-1}$ and $0.3 \mathrm{CFU} \mathrm{ml}^{-1} \pm 0.3 \mathrm{CFU} \mathrm{ml}^{-1}$, respectively, which is nearly a 5-log-unit reduction compared to the concentration in the pig slurry added to the soil surface 2 months earlier. Enterococcus spp. was only detected in the first weekly water sample while all subsequent weekly samples tested negative for Enterococcus spp. (Fig. 2b). The removal rates of Enterococcus spp. and $E$. coli were comparable at 3.1 and $3.3 \log \mathrm{m}^{-1}$, respectively.

The somatic coliphages were present in high numbers in drainage water immediately after application of slurry and was detected in the first five consecutive event samples from 6 October to 26 November. The removal rate of only $2.2 \mathrm{log}$ $\mathrm{m}^{-1}$ was calculated based on the first event sample that had the highest concentration of somatic coliphages at $1.4 \times 10^{3} \mathrm{PFU}$ $\mathrm{ml}^{-1} \pm 6.6 \times 10^{1} \mathrm{PFU} \mathrm{m}{ }^{-1}$. This was the lowest removal rate of any microorganism assayed (Table 2). The somatic coliphages reached the detection limit of the assay at the fifth event sample at the end of November. Somatic coliphages had a concentration of $345 \mathrm{PFU} \mathrm{ml}^{-1} \pm 32 \mathrm{PFU} \mathrm{m}^{-1}$ in the first weekly sample, but was subsequently not detected in weekly samples.

To evaluate the success of virus concentration and nucleic acid extraction, the recovery efficiency of $\mathrm{MC}_{0}$ for each individual sample was calculated. This resulted in a mean

Table 2 Microbial removal rates $\lambda$ determined from peak concentration $\left(C_{\max }\right)$ for the studied microorganisms in drain water event samples and well water samples

\begin{tabular}{llll}
\hline Microorganisms & \multicolumn{2}{l}{ Removal rate $\lambda\left(\log _{10} \mathrm{~m}^{-1}\right)$} \\
\cline { 2 - 4 } & Drain - event & Vertical well M5 & Horizontal well H \\
\hline E. coli & 3.3 & 3.4 & $\mathrm{ND}$ \\
Enterococcus spp. & 3.1 & 3.3 & $\mathrm{ND}$ \\
Somatic coliphages & 2.2 & 3.5 & $\mathrm{ND}$ \\
HEV & 3.1 & $\mathrm{ND}$ & $\mathrm{ND}$ \\
PCV2 & 3.3 & $\mathrm{ND}$ & $\mathrm{ND}$ \\
RV-A & 2.7 & 2.4 & 1.0 \\
\hline
\end{tabular}

$N D$ not detected recovery of $48.3 \% \pm 19.4$ in the range $11-96 \%$, with only one sample at each extreme. Thus, the analysis meets the criteria for successful extraction efficiency of $1 \%$ applied in the ISO/CEN method for virus detection in food and bottled water (ISO 2013).

HEV was detected only in the first event sample and correspondingly in the first weekly sample with both measurements close to the detection limit at 5 and 9 RT-PCRu ml ${ }^{-1}$, respectively. The removal rate calculated based on the event sample was $3.1 \log \mathrm{m}^{-1}$. Like HEV, the detection of PCV2 in water samples was low, ranging between 17 and 30 PCRu $\mathrm{ml}^{-1}$. PCV2 was detected in the first and second event sample along with the first weekly sample. The removal rate was 3.3 $\log \mathrm{m}^{-1}$ which was similar to that of HEV.

RV-A was by far the most abundant of the viruses detected in the pig slurry with $3.81 \times 10^{5}$ RT-PCRu ml ${ }^{-1}$ (Table 1). RVA was detected in the four first consecutive event samples and the concentration of RV-A increased in the drainage water over these four events (Fig. 2c). A removal rate of $2.7 \mathrm{log}$ $\mathrm{m}^{-1}$ was calculated based on the fourth event where the highest concentration of RV-A was detected. RV-A was also detected in weekly samples collected between 12 October 2011 and 16 December 2011, but absent in the following sample collected on 22 December 2011, then reappeared in the next sample collected during very heavy rainfall in the start of January, yielding high flow in the tile drains and a significant rise in groundwater levels. The same phenomenon was observed for enterococci. The RV-A concentration of the later samples were essentially at detection limit with 2 RTPCRu ml ${ }^{-1}$. For all PCR runs, all controls met their set criteria. An attempt to sequence all three viruses were made, but the viral load of the samples were too small to allow extract of sufficient genetic material.

\section{Well samples and groundwater}

At application of slurry, the groundwater level was close to drain level for two weeks followed by a slow decrease over the next 6 weeks. Hereafter the groundwater level again fluctuated at drain level (Fig. 2e). None of the microorganisms were detected in the water samples obtained from the vertical monitoring and the horizontal wells before application of pig slurry (Fig. 2d). Very low concentrations of E. coli $\left(0.4 \mathrm{CFU} \mathrm{m}{ }^{-1} \pm 0.4 \mathrm{CFU} \mathrm{ml}^{-1}\right)$ were detected in the vertical monitoring well at the start of December (day 57) while Enterococcus spp. was found at the start of November (day 29) and start of January (day 91) at similar low concentrations

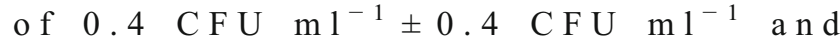
$0.7 \mathrm{CFU} \mathrm{ml}{ }^{-1} \pm 0.5 \mathrm{CFU} \mathrm{ml}^{-1}$, respectively, corresponding to a 5-log-unit reduction compared to the measured concentration in pig slurry (Table 1). Somatic coliphages were detected in the water sample collected in November (day 29) and December (day 57) from the vertical monitoring well, both at 
low concentrations, 1.2 PFU ml ${ }^{-1} \pm 0.6 \mathrm{PFU} \mathrm{ml}^{-1}$ and 0.7 $\mathrm{PFU} \mathrm{ml} \mathrm{m}^{-1} \pm 0.5 \mathrm{PFU} \mathrm{ml} \mathrm{C}^{-1}$, corresponding to more than a 5log-unit reduction (Fig. 2d) as compared to the pig slurry. RVA was detected in both the vertical monitoring well and the deeper horizontal well at the first sampling on 3 November. The following month, a small decrease in the concentration of RV-A in the vertical monitoring well and an above tenfold reduction in the horizontal well was observed. In January, RV-A was no longer detected in the horizontal well and barely detected in the vertical monitoring well, balancing on the detection limit of the assay (1.3 RT-PCR u ml${ }^{-1}$ ). Neither HEV nor PCV2 were found in any of the wells. The removal rate of E. coli, Enterococcus spp. and RV-A in the vertical well was similar to the rate detected in the drains while somatic coliphages increased by distance. In contrast, the removal rate of RV-A had decreased in the horizontal well indicating the possibility of extended transport distance for this virus.

\section{Microorganisms and slurry constituents}

All six microorganisms were detected in water samples from the tile drains in the first event sample, and correspondingly also in the first weekly sample (Fig. 2) while different leaching profiles between the microorganisms $(P=0.04)$ were observed during the study period. The leaching profiles of HEV, PCV2, somatic coliphages and Enterococcus spp. were very similar $(P=0.31)$ and showed a steep decline in concentration after the first week. Similar leaching profiles were observed between $E$. coli and RV-A $(P=0.07)$ and grouping them against the other four microorganisms showed that they were significantly different $(P=0.01)$.

During the study period, $\mathrm{pH}$ of the individual water samples, DOC, total dissolved phosphorus and particle-associated phosphorus content was also monitored in the weekly drainage water samples (Fig. 2a). A strong correlation of all analyzed microorganisms except RV-A to particle-associated phosphorus and DOC was found (Table 3). Conversely, RVA was the only microorganism correlating strongly to the dissolved phosphorus (Table 3). No correlation between the six microorganisms and the $\mathrm{pH}$ of the drainage water was observed.
The recovery of the microorganisms in the tile drains depended on the time of sampling and was associated with rain events (Table 4). The recovery was calculated based on the event sample with highest concentration of microorganism in tile drains. This was generally at $0.03-0.04 \%$ for all microorganisms except the RV-A and somatic coliphages, these had a recovery of 0.13 and $0.34 \%$, respectively, which was also reflected by their lower removal rate. When calculating the recovery of the microorganisms by summing all the event samples, they were comparable to the recovered concentration based on the maximum concentration sample; however, this was not true for RV-A (Table 4). The recoveries calculated on the two microorganisms with high concentration, RV-A and somatic coliphages, were far greater than the microorganisms with low concentration in manure.

\section{Discussion}

\section{Limitations of the study}

Comparing different microorganisms can be challenging due to the difference in available detection methods to assay each microorganism. rt-PCR was applied for detecting the genome of the porcine viruses, whereas phages and bacteria were detected by plaque assay and colony assay, respectively. These assays are not directly comparable as the plaque and colony assay accounts for viable phages and bacteria, versus the rtPCR assays that target the genomes of viruses and not only infectious particles. The study of enteric viruses by the use of rt-PCR have previously been performed in water samples, where infectivity correlated very well with rt-PCR detection (Borchardt et al. 2012) and a correlation between the survival of somatic coliphages and viral genome quantification has also been reported (Skraber et al. 2004).

Similar, detection of bacteria is faced by the challenge due to the differentiation of dead and live bacteria, and the differentiation of these from culturable and viable but nonculturable (VBNC) bacteria depending on the method employed. The limitation in the use of culturing and plaque assay is that not all pathogens of the same family are equally
Table 3 Correlation between the six studied microorganisms and selected chemical constituents in weekly drainage water samples. Significant values are highlighted in italic

\begin{tabular}{lllll}
\hline & $\mathrm{pH}$ & DOC & $\begin{array}{l}\text { Particle-associated } \\
\text { phosphorus }\end{array}$ & $\begin{array}{l}\text { Total dissolved } \\
\text { phosphorus }\end{array}$ \\
\hline HEV & 0.44 & 0.96 & 0.99 & 0.74 \\
PCV2 & 0.55 & 0.96 & 0.99 & 0.74 \\
RV-A & 0.46 & 0.69 & 0.79 & 0.94 \\
E. coli & 0.40 & 0.95 & 0.99 & 0.77 \\
Enterococcus spp. & 0.31 & 0.96 & 0.99 & 0.74 \\
Somatic coliphages & 0.39 & 0.96 & 0.99 & 0.74 \\
\hline
\end{tabular}


Table 4 Recovery (\%) of the six microorganisms in drainage water

\begin{tabular}{lccclll}
\hline & HEV & PCV2 & $\begin{array}{l}\text { RV- } \\
\text { A }\end{array}$ & $\begin{array}{l}\text { Somatic } \\
\text { coliphages }\end{array}$ & E. coli & $\begin{array}{l}\text { Enterococcus } \\
\text { spp. }\end{array}$ \\
\hline BTC peak concentration $\left(C_{\max }\right)$ & 0.04 & 0.03 & 0.13 & 0.34 & 0.03 & 0.04 \\
All event samples aggregated & 0.04 & 0.05 & 0.28 & 0.40 & 0.03 & 0.04 \\
All weekly samples aggregated & 0.11 & 0.07 & 0.20 & 0.35 & 0.06 & 0.04 \\
\hline
\end{tabular}

BTC breakthrough curve

suitable for culturing (Vaz-Moreira et al. 2013). Bacteria entering the VBNC- stage are unable to grow on traditional culture media (Colwell 2000), but the persistence of bacteria in soil does not seem to be promoted by entering the VBNCstage (Mascher et al. 2000). Discrepancy in the amount of viable and culturable bacteria compared to quantification of cell numbers based on DNA, which include culturable and non-culturable or dead cells, have been reported in environmental samples (Amin et al. 2013; Artz et al. 2006; Bech et al. 2010). In the current study, only viable $E$. coli, enterococci and somatic coliphages naturally occurring in the slurry and adapted to this environment were employed; furthermore, using a natural setting does not allow for perfectly timed samplings. This resulted in very low resolution of samples in this study and the scarce drainage runoff made it impossible to do additional analysis on larger volumes of water for viral analysis and also made duplicate measurements impossible without diluting samples.

\section{Leaching of microorganisms}

Colloids in the subsurface are characterized as mobile abiotic or biotic particles with a diameter less than $10 \mu \mathrm{m}$ and that possess an electric charge on their surface (McCarthy and Zachara. 1989). Colloids include layer silicates, sesquioxides, organic macromolecules and microorganisms, e.g. bacteria and viruses (Kretzschmar et al. 1999). Breakthrough was observed for all six microorganisms into drainage water 1 day after pig slurry was applied on the field. The leaching appeared to be influenced by preferential transport as evidenced by soil hydraulic properties and fast solute transport. Measured hydraulic characteristics in A and B horizons showed a marked increase in conductivity when approaching full saturation, also indicating a high degree of preferential flow through macropores when the soil is fully saturated (data not shown, see Lindhardt et al. 2001). Similar, manure applied microorganisms were detected in the drainage system only 1 day after application. The observed transport was thus considerably faster than that occurring through the soil matrix. Piston transport through the low-permeability soil matrix (Kjær et al. 2007) would involve a travel time to the drainage system of 69 days. This finding is consistent with previous transport studies conducted with other chemical compounds (Kjær et al. 2007, Norgaard et al. 2012, Naveed et al. 2016) as well as microorganisms (Bech et al. 2014) which showed similarly high degree of preferential flow at the Silstrup field. The leaching patterns of the microorganisms were interesting in that they appeared to have different leaching profiles. Somatic coliphages, HEV, PCV2 and Enterococcus spp. appeared immediately in drainage water in maximum concentrations followed by a rapid decrease, while leaching of $E$. coli and RV-A was observed for an extended period. The leaching of microorganism through soil depends on the extent of their retention in the soil profile as well as their ability to survive in the soil environment (Ginn et al. 2002; Yates and Yates 1990). In structured soils, most studies of microbial transport generally show a rapid movement of bacteria and viruses due to preferential flow through macropores, e.g. naturally occurring cracks, fractures, earthworm holes, and channels formed by plant roots resulting in an early breakthrough, thereby bypassing much of the soil matrix (Abu-Ashour et al. 1994; Pang et al. 2008). Similar leaching patterns have been reported for phages and E. coli in field studies (Schijven et al. 1999; Vinten et al. 2002). Differences in leaching between $E$. coli and enterococci have been ascribed to a stronger attachment of E. coli to soil particles (Evans and Owens 1972). In the present study, the removal rate was similar for E. coli and enterococci; however, $E$. coli was detected for a prolonged period in the weekly samples which could indicate slower migration due to increased attachment to soil particles which was also observed for RV-A. When comparing the abundant RV-A and somatic coliphages, a clearly distinct leaching profile was seen in the weekly samples, and interestingly, an opposite leaching profile was observed in the first four event samples. RV-A concentration increased in drainage water during the first 2 weeks, whereas the concentration of somatic coliphages decreased. These very distinct leaching profiles of the two microorganisms, indicates that RV-A differs considerably with respect to the initial redistribution of the liquid phase of slurry in soil. Leaching of RV-A correlated with dissolved phosphorus indicating less interaction with the slurry and soil particles within the soil matrix. Somatic coliphages correlated with particleassociated phosphorus indicating a rapid transport through the soil in the preferential flow path which could be due to size exclusion. Studies on particle size-fractionated separated pig slurry have shown that phosphorous was present in larger proportions in particles less than $25 \mu \mathrm{m}$ (Peters et al. 2011). Similarly, Amin et al. (2013) found evidence for an effect of 
microbial cell size on the redistribution and leaching potential of slurry-borne pathogens in soil. This indicates that somatic coliphages, due to difference in size and physiochemical properties, are inadequate indicators for RV-A and probably other viruses that share this difference. These observations may only hold true under the conditions reported here, e.g. soil type, temperature and hydrological characteristics.

The high concentration of RV-A detected in the shallow screen of the vertical monitoring well and the detection of $\mathrm{RV}-\mathrm{A}$ in the deeper horizontal well was unique for RV-A. None of the other microorganisms were detected in the horizontal well ( $3.5 \mathrm{~m} \mathrm{bgs})$. The difference in the detected levels of RV-A and somatic coliphages in the vertical monitoring well could be caused by the faster transport of somatic coliphages, i.e. the coliphages had passed the vertical monitoring well at time of sampling, whereas RV-A peaked at time of sampling. The sudden increase in removal rate for somatic coliphages in the vertical well compared to drains, as well as the decrease in removal rate for RV-A in the horizontal well compared with the drains and vertical well, could also indicate this. The lower removal rate of RV-A is in line with Pang (2009) reporting lower removal rates of enteroviruses compared to bacteriophages and other human viruses. This detection of RV-A in this deeper well is of major concern, since RV$\mathrm{A}$ is a known cause of enteric disease in humans and animals, and zoonotic transmissions have been described at several occasions (Martella et al. 2010; Midgley et al. 2012). In addition, E. coli and Enterococcus spp. were also detected in the monitoring well. Shallow wells have previously been reported to be particularly susceptible to contamination of fecal bacteria from agricultural activities in clay rich sediments (Conboy and Goss 2000). The occurrence of fecal coliforms in tile drainage water in field experiments has been reported previously (Patni et al. 1984; Scott et al. 1998; Vinten et al. 2002). In the study reported here, a recovery of $0.03-0.06 \%$ was found which is in accordance with results of similar field studies (Evans and Owens 1972; Vinten et al. 2002). This is further corroborated by the $E$. coli recovery obtained in a leaching experiment performed on intact soil cores using soil of similar composition (Forslund et al. 2011b). The recoveries of HEV and PCV2 were comparable to that of E. coli and Enterococcus spp., whereas the recovery of RV-A was similar to that of somatic coliphages.

Several factors have been ascribed to enhance migration of microorganisms through soil, e.g. straining, $\mathrm{pH}$, precipitation and manure constituents (Abu-Ashour et al. 1994; Bradford et al. 2002). The viruses HEV, PCV2, and RV-A have been reported to have a diameter of approximately 32,17 and $70 \mathrm{~nm}$, respectively, whereas the somatic coliphages ranges from 24 to $200 \mathrm{~nm}$ (Burbano-Rosero et al. 2011). Viruses with smaller size can easily move into the soil matrix by diffusion and aggregate during the initial redistribution, which protects them from subsequent preferential flow events (Yates and
Yates 1990). During subsequent heavy rain events the viruses can be released and leach through the soil profile; however previous reports have indicated that straining has a larger effect on bacteria $(0.5-2 \mu \mathrm{m})$ than on viruses, as viruses generally are smaller than the pore size of the soil; hence, straining on viruses due to size should be negligible (Lance and Gerba 1984).

The isoelectric point, the $\mathrm{pH}$ where the net charge of the total particle surface is zero, is another important factor that may impact leaching of microorganisms (Dowd et al. 1998; Jamieson et al. 2002; Schijven and Hassanizadeh 2000). The isoelectric point of two different strains of RV-A have been reported with different results. An isoelectric point of 8.0 was measured on the simian rotavirus SA-11 (Butler et al. 1985) and more recently, a porcine rotavirus with an isoelectric point of 4.5 was reported (Gutierrez et al. 2009). The exceptional high isoelectric point of RV-A reported by Butler et al. (1985) could explain the difference in leaching pattern of RV-A compared to other microorganisms observed in this study, as the net positive charge of RV-A at neutral $\mathrm{pH}$ would allow for adhesion on the negatively charged soil particles. The low isoelectric point of 4.5 is in the range of many enteric viruses and phages (Michen and Graule 2010) which at neutral pH gives a negative net charge of the particle and would result in repulsion from the negatively charged soil particles. Even though the overall charge of the particle is negative, there can still be local areas of positive charge, thus a larger particle will allow for more positively charged areas, capable of interactions with soil particles (Dowd et al. 1998). In the work by Dowd et al. (1998) it was also shown that phages less than $60 \mathrm{~nm}$ in diameter were dependent on isoelectric point for adhesion, whereas size became the determining factor for adhesion properties of particles larger than $60 \mathrm{~nm}$ in diameter. This corresponds very well with data on viruses acquired during this study, where a retention of the larger RV-A particle $(70 \mathrm{~nm})$ compared to the much smaller HEV $(32 \mathrm{~nm})$ and PCV2 $(17 \mathrm{~nm})$ particles is observed.

Precipitation events occurring immediately after manure application facilitated a rapid transport of microorganisms via preferential pathways. In addition, heavy rainfall occurring 3 months after application promoted the leaching of Enterococcus spp. and RV-A to the tile drain and monitoring well. This is corroborated by a study showing that pathogen transport through soil to drinking water wells is promoted by heavy rainfall (Lamka et al. 1980).

Manure constituents such as DOC have been shown to enhance leaching of microorganisms by competing with favorable adhesion sites on soil particles (Bradford et al. 2006; Gerba 1984; Guber et al. 2007). Royer et al. (2007) showed that surface application of manure to a field resulted in immediate leaching of DOC in tile drains indicating preferential flow. Similar increased levels of DOC after application of pig slurry were also observed in the present study. Leaching 
of all microorganisms except RV-A correlated well to the leaching of DOC and particle-associated phosphorus, i.e. phosphorous that is bound to particles and also phosphorous bound in microorganisms. Phosphorus is generally considered to be well adsorbed by the soil matrix, but it has been shown that particle-associated phosphorus adsorbed to a lesser extent than dissolved phosphorus (Glæsner et al. 2011). The transport of particle-associated phosphorus would, due to the particle mediated transport, be enhanced and be restricted to larger pores and fractures in the soil profile, thus indicating preferential flow. The leaching of RV-A on the other hand had a high correlation with the dissolved phosphorus which could indicate a lower adsorption to the slurry and soil particles resulting in slower transport through soil compared to particle mediated transport.

\section{Environmental and water safety hazards}

The survival of a microorganism is an important factor for determining water contamination and the potential hazard this entails. It was possible to detect $E$. coli and somatic coliphages for at least two months, while Enterococcus spp. was detected through the entire study period. Cools et al. (2001) reported the survival of enterococci to be higher than that of $E$. coli in multiple soil compositions at temperatures below $15^{\circ} \mathrm{C}$ and at different moisture contents, which is in contrast to Pourcher et al. (2007) that reported no difference in survival of these two fecal indicators; however, in both studies enterococci and $E$. coli survived for more than 2 months. The survival of somatic coliphages has been reported to be high with detection of infectious somatic coliphages in soil for 143 days post manure application (Gessel et al. 2004). The survival of somatic coliphages has been shown to correlate to viral genome quantification, but not to fecal indicator organisms which survived for a shorter period (Skraber et al. 2004); however, it was found that leaching of Enterococcus spp. exceeded that of $E$. coli and somatic coliphages which again exceeded that of $\mathrm{HEV}$ and PCV2. The presence of HEV in the water environment of the western world has recently been recognized (Christou and Kosmidou 2013). There have previously been reports of $\mathrm{HEV}$ in urban sewage samples from Europe and USA (Clemente-Casares et al. 2003) and that it can survive for at least 1 month in sewage (Pina et al. 1998). These studies and the one reported here are all based on PCR detection and does not confirm the presence of viable viruses; furthermore, $\mathrm{HEV}$ viruses have been shown to survive for 9 weeks at fluctuating temperature in soil and for 10 weeks at $37^{\circ} \mathrm{C}$ (Parashar et al. 2011). Surveys have found HEV in shellfish, and a study in the United Kingdom showed a prevalence of 50-96\% HEV RNA in shellfish from coastal areas (Crossan et al. 2012). An epidemiological study of autochthonously acquired cases of $\mathrm{HEV}$ was linked to consuming water from a private drinkingwater well in France (Renou et al. 2008). The majority of privately owned wells reside in rural areas, and therefore in close proximity of farmland, where wells are at risk of microbial contamination from land application of fecal originated wastes (Bradbury et al. 2013; Lamka et al. 1980). Since some viruses have been shown to be transported in water reservoirs for longer than $400 \mathrm{~m}$ horizontally and more than $60 \mathrm{~m}$ vertically (Keswick and Gerba 1980), the leaching of pathogens into the groundwater, after spread of manure, could expose humans to these pathogens by migrating into wells. Combined with the high stability of some of these viruses, there is a real risk for these viruses causing clinical illness. The survival of PCV2 have proved to be high with PCV2 being one of the most stable porcine viruses even withstanding disinfectants (Kim et al. 2009) and therefore difficult to eradicate in swineherds. The possibility that PCV2 circulates in the water environment could also contribute to the risk of introducing or reintroducing PCV2 into susceptible swine herds. RV-A have previously been detected in drinking water (Gerba et al. 1996). RV-A potentially poses a large problem, primarily due to the very large amount of virus excreted from animals and humans, high stability in water and zoonotic potential (Gerba et al. 1996; Martella et al. 2010). The survival of human rotavirus in river water and tap water has been shown to be at least 60 days at $4-20{ }^{\circ} \mathrm{C}$ (Raphael et al. 1985). Similarly, the time to reduce $90 \%$ of infectious calf rotavirus in distilled water and sewage was shown to be 73 and 84 days, respectively (McDaniels et al. 1983). In this field study it was found that RV-A was detectable in groundwater and persisted there for at least 3 months following application of pig slurry and the soil temperature measured during the study period would also favor an extended persistence of the microorganisms.

\section{Conclusion}

This field study investigated the simultaneous transport of RVA, HEV, PCV2 and somatic coliphages under natural condition along with the leaching of E. coli and Enterococcus spp. through soil. The results showed immediate leaching of all microorganisms to the tile drain. E. coli and RV-A had similar leaching pattern but different from somatic coliphages, PCV2, HEV and Enterococcus spp. The data generated in the present study suggest that somatic coliphages can be used to model transport of some viruses in soil, e.g. HEV and PCV2 but does not necessarily cover all viruses. This paper reports different leaching patterns of RV-A. The exact reason for this is not clear based on the data, but size exclusion or difference in physiochemical properties are likely to play a key role here. Furthermore, only RV-A was detected in the horizontal well corresponding to leaching into the shallow groundwater, making RV-A a possible risk due to its high mobility, stable nature, high copy number and high prevalence in pig and cattle herds, 
suggesting that this virus should be monitored more closely considering its zoonotic potential. As drainage water is led into surface water reservoirs this could pose a health risk to humans and animals exposed to these water resources. The authors therefore recommend future work on assessment of human health risk related to contamination of surface water reservoirs from manureborne microorganisms leaching to tiledrains.

Acknowledgements We would like to thank Jens Molbo, Lasse Gudmundsson (ongoing field monitoring and data preparation), Gitte Petersen, Nina Flindt (laboratory assistance) and Bo Markussen (statistical support). The study was supported by the PATHOS project (From manure to freshwater-technology avoiding contamination with pathogens, hormones and pharmaceutical; http://www.pathos.geus.net) supported by the Danish Council for Strategic Research (ENV 2104-070015), the EU-funded PathOrganic under the CoreOrganic ERA-net (project No. 1888; http://core1.coreorganic.org/research/projects/ pathorganic/index.html) and Aquavalens (EU FP7-KBBE-2012-6; http://aquavalens.org/), The Danish Pesticide Leaching Assessment Programme (http://pesticidvarsling.dk/om_os_uk/uk-forside.html) and the Ministry of Food, Agriculture and Fisheries of Denmark (DFFE) for funding (project number 3304-FVFP 09-F-011).

Open Access This article is distributed under the terms of the Creative Commons Attribution 4.0 International License (http:// creativecommons.org/licenses/by/4.0/), which permits unrestricted use, distribution, and reproduction in any medium, provided you give appropriate credit to the original author(s) and the source, provide a link to the Creative Commons license, and indicate if changes were made.

\section{References}

Abu-Ashour J, Joy D, Lee H, Whiteley H, Zelin S (1994) Transport of microorganisms through soil. Water Air Soil Pollut 75(1):141-158. doi:10.1007/BF01100406

Abu-Ashou J, Joy DM, Lee H, Whiteley HR HR, Zelin S (1998) Movement of bacteria in unsaturated soil columns with macropores. Trans ASAE 41:1043-1050. doi:10.13031/2013.17267

Amin MGM, Forslund A, Bui XT, Juhler RK, Petersen SO, Lægdsmand M (2013) Persistence and leaching potential of microorganisms and mineral $\mathrm{N}$ in animal manure applied to intact soil columns. Appl Environ Microbiol 79(2):535-542. doi:10.1128/AEM.02506-12

Artz RRE, Avery LM, Jones DL, Killham K (2006) Potential pitfalls in the quantitative molecular detection of Escherichia coli $\mathrm{O} 157: \mathrm{H} 7$ in environmental matrices. Can J Microbiol 52(5):482-488. doi:10.1139/w05-149

Azadpour-Keeley A, Faulkner BR, Chen J-S (2003) Movement and longevity of viruses in the subsurface. US Environmental Protection Agency, National Risk Management Research Lab., Washington, $\mathrm{DC}$

Bech TB, Johnsen K, Dalsgaard A, Laegdsmand M, Jacobsen OH, Jacobsen CS (2010) Transport and distribution of Salmonella enterica Serovar Typhimurium in loamy and sandy soil monoliths with applied liquid manure. Appl Environ Microbiol 76(3):710 714. doi:10.1128/AEM.00615-09

Bech TB, Rosenbom AE, Kjaer J, Amin MMG, Olsen P, Jacobsen CS (2014) Factors influencing the survival and leaching of tetracyclineresistant bacteria and Escherichia coli through structured agricultural fields. Agr Ecosyst Environ 195:10-17. doi:10.1016/j. agee.2014.05.017

Beven K, Germann P (1982) Macropores and water flows in soil. Water Resour Res 18:1311-1325. doi:10.1029/WR018i005p01311

Borchardt MA, Bradbury KR, Alexander EC, Kolberg RJ, Alexander SC, Archer JR, Braatz LA, Forest BM, Green JA, Spencer SK (2011) Norovirus outbreak caused by a new septic system in a dolomite aquifer. Ground Water 49(1):85-97. doi:10.1111/j.17456584.2010.00686.x

Borchardt MA, Spencer SK, Kieke BA, Lambertini E, Loge FJ (2012) Viruses in nondisinfected drinking water from municipal wells and community incidence of acute gastrointestinal illness. Environ Health Perspect 120(9):1272-1279. doi:10.1289/ehp.1104499

Bosch A (1998) Human enteric viruses in the water environment: a minireview. Int Microbiol 1(3):191-196

Bouwknegt M, Engel B, Herremans M, Widdowson M, Worm H, Koopmans M, Frankena K, de Roda HA, De Jong M, Van Der Poel W (2008) Bayesian estimation of hepatitis E virus seroprevalence for populations with different exposure levels to swine in the Netherlands. Epidemiol Infect 136(4):567-576. doi:10.1017 /s0950268807008941

Bradbury KR, Borchardt MA, Gotkowitz M, Spencer SK, Zhu J, Hunt RJ (2013) Source and transport of human enteric viruses in deep municipal water supply wells. Environ Sci Technol 47(9):4096-4103. doi:10.1021/es400509b

Bradford SA, Yates SR, Bettahar M, Simunek J (2002) Physical factors affecting the transport and fate of colloids in saturated porous media. Water Resour Res 38(12):1327. doi:10.1029/2002WR001340

Bradford SA, Simunek J, Bettahar M, van Genuchten MT, Yates SR (2006) Significance of straining in colloid deposition: evidence and implications. Water Resour Res 42(12):W12S15. doi:10.1029 /2005WR004791

Bradford SA, Morales VNL, Zhang W, Harvey RW, Packman AI, Mohanram A, Welty C (2013) Transport and fate of microbial pathogens in agricultural settings. Crit Rev Environ Sci Technol 43(8): 775-893. doi:10.1080/10643389.2012.710449

Breum SO, Hjulsager CK, de Deus N, Segales J, Larsen LE (2010) Hepatitis E virus is highly prevalent in the Danish pig population. Vet Microbiol 146(1-2):144-149. doi:10.1016/j. vetmic.2010.05.002

Burbano-Rosero EM, Ueda-Ito M, Kisielius JJ, Nagasse-Sugahara TK, Almeida BC, Souza CP, Markman C, Martins GG, Albertini L, Rivera ING (2011) Diversity of somatic coliphages in coastal regions with different levels of anthropogenic activity in São Paulo State, Brazil. Appl Environ Microbiol 77(12):4208-4216. doi:10.1128/AEM.02780-10

Butler M, Medien A, Taylor G (1985) Electrofocusing of viruses and sensitivity to disinfection. Water Sci Technol 17(10):201-210

Christensen PB, Engle RE, Hjort C, Homburg KM, Vach W, Georgsen J, Purcell RH (2008) Time trend of the prevalence of hepatitis E antibodies among farmers and blood donors: a potential zoonosis in Denmark. Clin Infect Dis 47(8):1026-1031. doi:10.1086/591970

Christou L, Kosmidou M (2013) Hepatitis E virus in the Western world: a pork-related zoonosis. Clin Microbiol Infect 19(7):600-604. doi:10.1111/1469-0691.12214

Chu Y, Jin Y, Flury M, Yates MV (2001) Mechanisms of virus removal during transport in unsaturated porous media. Water Resour Res 1(37):253-263. doi:10.1029/2000wr900308

Clemente-Casares P, Pina S, Buti M, Jardi R, MartIn M, Bofill-Mas S, Girones R (2003) Hepatitis E virus epidemiology in industrialized countries. Emerg Infect Dis 9(4):448-454. doi:10.3201 /eid0904.020351

Cole DJ, Hill VR, Humenik FJ, Sobsey MD (1998) Health, safety, and environmental concerns of farm animal waste. Occup Med 14(2): 423-448 
Colwell RR (2000) Viable but nonculturable bacteria: a survival strategy. J Infect Chemother 6(2):121-125. doi:10.1007/p100012151

Conboy MJ, Goss MJ (2000) Natural protection of groundwater against bacteria of fecal origin. J Contam Hydrol 43(1):1-24. doi:10.1016 /s0169-7722(99)00100-x

Cools D, Merckx R, Vlassak K, Verhaegen J (2001) Survival of E. coli and Enterococcus spp. derived from pig slurry in soils of different texture. Appl Soil Ecol 17(1):53-62

Costafreda MI, Bosch A, Pinto RM (2006) Development, evaluation, and standardization of a real-time TaqMan reverse transcription-PCR assay for quantification of hepatitis A virus in clinical and shellfish samples. Appl Environ Microbiol 72(6):3846-3855. doi:10.1128 /AEM.02660-05

Croci L, Dubois E, Cook N, de Medici D, Schultz A, China B, Rutjes S, Hoorfar J, Van der Poel W (2008) Current methods for extraction and concentration of enteric viruses from fresh fruit and vegetables: towards international standards. Food Anal Methods 1(2):73-84. doi:10.1007/s12161-008-9025-4

Crossan C, Baker PJ, Craft J, Takeuchi Y, Dalton HR, Scobie L (2012) Hepatitis E virus genotype 3 in shellfish, United Kingdom. Emerg Infect Dis 18(12):2085-2087. doi:10.3201/eid1812.120924

Danish Agriculture and Food Council (2012) 26.000.000.000 kilo gylle skal ud. http:/www.foodculture.dk/produktion/landbrug/2012/kilogylle-skal-ud.aspx. Accessed 14 May 2016

Danish Standard (1997) Water analysis: guidelines for the determination of total organic carbon (TOC) and dissolved organic carbon (DOC). DS/EN 1484:1997. Danish Standard, Copenhagen, Denmark

Danish Standard (1999) Environmental quality: enumeration of enterococci-colony count on solid medium-spread plate method. DS2401. Danish Standard, Copenhagen, Denmark

Danish Standard (2004) Water quality: determination of phosphorusammonium molybdate spectrometric method. DS/EN ISO 6878: 2004. Danish Standard, Copenhagen, Denmark

DeBorde DC, Woessner WW, Lauerman B, Ball PN (1998) Virus occurrence and transport in a school septic system and unconfined aquifer. Ground Water 36(5):825-834. doi:10.1111/j.1745-6584.1998. tb02201.x

de Jonge LW, Moldrup P, Rubaek GH, Schelde K, Djurhuus J (2004) Particle leaching and particle-facilitated transport of phosphorus at field scale. Vadose Zone J 3(2):462-470. doi:10.2113/3.2.462

Dowd SE, Pillai SD, Wang S, Corapcioglu MY (1998) Delineating the specific influence of virus isoelectric point and size on virus adsorption and transport through sandy soils. Appl Environ Microbiol 64(2):405-410

Emelko MB, Schmidt PJ, Roberson JA (2008) Quantification of uncertainty in microbial data: reporting and regulatory implications. J Am Water Works Assoc 100(3):94-104

Ernstsen V (2004) Delimitation of pesticide sensitive areas (KUPA) - Test methods in preparation for a mapping concept for Danish clay soils. Status report. Geological Survey of Denmark and Greenland (GEUS), Ministry of Environment and Danish Agricultural Sciences (DJF), Ministry of Food, Agriculture and Fisheries. (In Danish), 208 pp. http://kupa.dk/xpdf/KUPA ler statusrapport.pdf. Accessed 10 October 2016

Evans MR, Owens JD (1972) Factors affecting the concentration of faecal bacteria in land-drainage water. J Gen Microbiol 71(3):477-485. doi:10.1099/00221287-71-3-477

Fleming R, Bradshaw PES (1992) Contamination of subsurface drainage systems during manure spreading, Paper no. 92-2618, ASAE, Nashville, TN

Flury M (1996) Experimental evidence of transport of pesticides through field soils: a review. J Environ Qual 25(1):25-45

Foged HL, Flotats X, Blasi AB, Palatsi J, Magri A, Schelde KM (2011) Inventory of manure processing activities in Europe. Technical report no. I concerning "Manure Processing Activities in Europe" to the European Commission, Directorate-General Environment, EC, Brussels, $138 \mathrm{pp}$

Fong T-T, Lipp EK (2005) Enteric viruses of humans and animals in aquatic environments: health risks, detection, and potential water quality assessment tools. Microbiol Mol Biol Rev 69(2):357-371. doi:10.1128/mmbr.69.2.357-371.2005

Forslund A, Plauborg F, Andersen MN, Markussen B, Dalsgaard A (2011a) Leaching of human pathogens in repacked soil lysimeters and contamination of potato tubers under subsurface drip irrigation in Denmark. Water Res 45(15):4367-4380. doi:10.1016/j. watres.2011.05.009

Forslund A, Markussen B, Toenner-Klank L, Bech TB, Jacobsen OS, Dalsgaard A (2011b) Leaching of Cryptosporidium parvum oocysts, Escherichia coli, and a Salmonella enterica Serovar Typhimurium bacteriophage through intact soil cores following surface application and injection of slurry. Appl Environ Microbiol 77(22):8129-8138. doi:10.1128/aem.05675-11

Gerba CP (1984) Applied and theoretical aspects of virus adsorption to surfaces. Adv Appl Microbiol 30:133-168. doi:10.1016/s00652164(08)70054-6

Gerba CP, Rose JB, Haas CN, Crabtree KD (1996) Waterborne rotavirus: a risk assessment. Water Res 30(12):2929-2940. doi:10.1016 /s0043-1354(96)00187-x

Gessel PD, Hansen NC, Goyal SM, Johnston LJ, Webb J (2004) Persistence of zoonotic pathogens in surface soil treated with different rates of liquid pig manure. Appl Soil Ecol 25(3):237-243. doi:10.1016/j.apsoil.2003.09.008

Gibson KE, Schwab KJ (2011) Detection of bacterial indicators and human and bovine enteric viruses in surface water and groundwater sources potentially impacted by animal and human wastes in Lower Yakima Valley, Washington. Appl Environ Microbiol 77(1):355362. doi:10.1128/aem.01407-10

Ginn TR, Wood BD, Nelson KE, Scheibe TD, Murphy EM, Clement TP (2002) Processes in microbial transport in the natural subsurface. Adv Water Resour 25(8-12):1017-1042

Gjettermann B, Petersen CT, Koch CB, Spliid NH, Gron C, Baun DL, Styczen M (2009) Particle-facilitated pesticide leaching from differently structured soil monoliths. J Environ Qual 38(6):2382-2393. doi: $10.2134 /$ jeq2008.0417

Glæsner N, Kjaergaard C, Rubæk GH, Magid J (2011) Interactions between soil texture and placement of dairy slurry application: II. leaching of phosphorus forms. J Environ Qual 40(2):344-351. doi:10.2134/jeq2010.0318

Guber AK, Pachepsky YA, Shelton DR, Yu O (2007) Effect of bovine manure on fecal coliform attachment to soil and soil particles of different sizes. Appl Environ Microbiol 73(10):3363-3370. doi:10.1128/aem.02434-06

Gutierrez L, Li X, Wang J, Nangmenyi G, Economy J, Kuhlenschmidt TB, Kuhlenschmidt MS, Nguyen TH (2009) Adsorption of rotavirus and bacteriophage MS2 using glass fiber coated with hematite nanoparticles. Water Res 43(20):5198-5208. doi:10.1016/j. watres.2009.08.031

Harris L, Farber J, Beuchat L, Parish M, Suslow T, Garrett E, Busta F (2003) Outbreaks associated with fresh produce: incidence, growth, and survival of pathogens in fresh and fresh-cut produce. Compr Rev Food Sci Food Saf 2(s1):78-141. doi:10.1111/j.15414337.2003.tb00031.x

Havelaar A (1991) Bacteriophages as model viruses in water quality control. Water Res 25(5):529-545. doi:10.1016/0043-1354(91 )90126-b

Hijnen WA, Brouwer-Hanzens AJ, Charles KJ, Medema GJ (2005) Transport of MS2 phage, Escherichia coli, Clostridium perfringens, Cryptosporidium parvum, and Giardia intestinalis in a gravel and a sandy soil. Environ Sci Technol 39(20):7860-7868. doi:10.1021 les050427b 
Hjulsager CK, Grau-Roma L, Sibila M, Enøe C, Larsen L, Segalés J (2009) Inter-laboratory and inter-assay comparison on two realtime PCR techniques for quantification of PCV2 nucleic acid extracted from field samples. Vet Microbiol 133(1-2):172-178. doi:10.1016/j.vetmic.2008.06.014

Hrudey SE, Huck P, Payment P, Gillham R, Hrudey E (2002) Walkerton: lessons learned in comparison with waterborne outbreaks in the developed world. J Environ Eng Sci 1(6):397-407. doi:10.1139 /s02-031

Hsieh SY, Meng XJ, Wu YH, Liu ST, Tam AW, Lin DY, Liaw YF (1999) Identity of a novel swine hepatitis $\mathrm{E}$ virus in Taiwan forming a monophyletic group with Taiwan isolates of human hepatitis E virus. J Clin Microbiol 37(12):3828-3834

ISO (2001) Water Quality: detection and enumeration of bacteriophages - part 2, enumeration of somatic coliphages. DS/EN ISO 10705-2, Danish Standard, Copenhagen, Denmark

ISO (2013) ISO/TS 15216-1:2013 Microbiology of food and animal feed: horizontal method for determination of hepatitis A virus and norovirus in food using real-time RT-PCR - part 1, method for quantification, part 2, method for quantitative determination, ISO, Geneva

Jacobsen OH, Kjaer J (2007) Is tile drainage water representative of root zone leaching of pesticides? Pest Manag Sci 63(5):417-428. doi: $10.1002 /$ ps. 1372

Jamieson R, Gordon R, Sharples K, Stratton G, Madani A (2002) Movement and persistence of fecal bacteria in agricultural soils and subsurface drainage water: a review. Can Biosyst Eng 44:1-9

Jansons J, Edmonds LW, Speight B, Bucens MR (1989) Movement of viruses after artificial recharge. Water Res 23(3):293-299. doi:10.1016/0043-1354(89)90094-8

Jarvis NJ (2007) A review of non-equilibrium water flow and solute transport in soil macropores: principles, controlling factors and consequences for water quality. Eur J Soil Sci 58(3):523-546. doi:10.1111/j.1365-2389.2007.00915.x

Jiang S, Noble R, Chu W (2001) Human adenoviruses and coliphages in urban runoff-impacted coastal waters of Southern California. Appl Environ Microbiol 67(1):179-184. doi:10.1128/aem.67.1.179184.2001

Keswick BH, Gerba CP (1980) Viruses in groundwater. Environ Sci Technol 14(11):1290-1297. doi:10.1021/es60171a602

Kim HB, Lyoo KS, Joo HS (2009) Efficacy of different disinfectants in vitro against porcine circovirus type 2. Vet Rec 164(19):599600. doi:10.1136/vr.164.19.599

Kjær J, Ernstsen V, Jacobsen OH, Hansen N, de Jonge LW, Olsen P (2011) Transport modes and pathways of the strongly sorbing pesticides glyphosate and pendimethalin through structured drained soils. Chemosphere 84(4):471-479. doi: $10.1016 / \mathrm{j}$. chemosphere.2011.03.029

Kjær J, Olsen P, Bach K, Barlebo HC, Ingerslev F, Hansen M, Sørensen BH (2007) Leaching of estrogenic hormones from manure-treated structured soils. Environ Sci Technol 41(11):3911-3917. doi:10.1021/es0627747

Klint KE, Gravesen P (1999) Fractures and biopores in Weichselian clayey till aquitards at Flakkebjerg, Denmark. Hydrol Res 30(4-5):267

Kristensen CS, Hjulsager CK, Vestergaard K, Dupont K, Bille-Hansen V, Enøe C, Jorsal SE, Bækbo P, Larsen LE (2013) Experimental airborne transmission of porcine postweaning multisystemic wasting syndrome. J Pathog 2013:1-7. doi:10.1155/2013/534342

Kretzschmar R, Borkovec M, Grolimund D, Elimelech M (1999) Mobile subsurface colloids and their role in contaminant transport. Adv Agronomy 66(66):121-193

Lamka KG, LeChevallier MW, Seidler RJ (1980) Bacterial contamination of drinking water supplies in a modern rural neighborhood. Appl Environ Microbiol 39(4):734-738

Lance JC, Gerba CP (1984) Virus movement in soil during saturated and unsaturated flow. Appl Environ Microbiol 47(2):335-337
Lee HS (2009) Somatic coliphage families as potential indicators of enteric viruses in water and methods for their detection. $\mathrm{PhD}$ Thesis, University of North Carolina, Chapel Hill, NC

Lindhardt B, Abildtrup C, Vosgerau H, Olsen P, Torp S, Iversen BV, Jørgensen JO, Plauborg F, Rasmussen P, Gravesen P (2001) The Danish pesticide leaching assessment programme: site characterization and monitoring design. Geological Survey of Denmark and Greenland, Copenhagen. http://pesticidvarsling.dk/monitor uk/plap_site_char_2001.html. Accessed 10 October 2016

Lipp E, Rose J (1997) The role of seafood in foodborne diseases in the United States of America. Rev Sci Tech 16(2):620-640. doi:10.20506/rst.16.2.1048

Mansuy J-M, Bendall R, Legrand-Abravanel F, Sauné K, Miédouge M, Ellis V, Rech H, Destruel F, Kamar N, Dalton HR (2011) Hepatitis E virus antibodies in blood donors, France. Emerg Infect Dis 17(12): 2309-2312. doi:10.3201/eid1712.110371

Martella V, Bányai K, Matthijnssens J, Buonavoglia C, Ciarlet M (2010) Zoonotic aspects of rotaviruses. Vet Microbiol 140(3-4):246-255. doi:10.1016/j.vetmic.2009.08.028

Mascher F, Hase C, Moënne-Loccoz Y, Défago G (2000) The viable-butnonculturable state induced by abiotic stress in the biocontrol agent pseudomonas fluorescens CHA0 does not promote strain persistence in soil. Appl Environ Microbiol 66(4):1662-1667. doi:10.1128/AEM.66.4.1662-1667.2000

McCarthy JF, Zachara JM (1989) Subsurface transport of contaminants. Environ Sci Technol 23:496-502

McDaniels AE, Cochran KW, Gannon JJ, Williams GW (1983) Rotavirus and reovirus stability in microorganism-free distilled and wastewaters. Water Res 17(10):1349-1353. doi:10.1016/0043-1354(83 )90263-4

McLellan J, Fleming R, Bradshaw S, Center S (1993) Reducing manure output to streams from subsurface drainage systems. ASAE. St. Joseph, MI

Meng X-J, Purcell RH, Halbur PG, Lehman JR, Webb DM, Tsareva TS, Haynes JS, Thacker BJ, Emerson SU (1997) A novel virus in swine is closely related to the human hepatitis E virus. Proc Natl Acad Sci U S A 94(18):9860-9865. doi:10.1073/pnas.94.18.9860

Mesquita MMF, Emelko MB (2012) Bacteriophages as surrogates for the fate and transport of pathogens in source water and in drinking water treatment processes In: Kurtboke I (ed) Bacteriophages. InTech. http://www.intechopen.com/books/bacteriophages. Accessed January 2017

Michen B, Graule T (2010) Isoelectric points of viruses. J Appl Microbiol 109(2):388-397. doi:10.1111/j.1365-2672.2010.04663.x

Midgley S, Hjulsager C, Larsen L, Falkenhorst G, Böttiger B (2012) Suspected zoonotic transmission of rotavirus group A in Danish adults. Epidemiol Infect 140(6):1013-1017. doi:10.1017 /S0950268811001981

Naden PS, Old GH, Eliot-Laize C, Granger SJ, Hawkins JM, Bol R, Haygarth P (2010) Assessment of natural fluorescence as a tracer of diffuse agricultural pollution from slurry spreading on intenselyfarmed grasslands. Water Res 44(6):1701-1712

Naik SR, Aggarwal R, Salunke PN, Mehrotra NN (1992) A large waterborne viral hepatitis E epidemic in Kanpur, India. Bull World Health Org 70(5):597-604. doi:10.1007/BF02821726

Naveed M, Moldrup P, Schaap MG, Tuller M, Kulkarni R, Vogel HJ, de Jonge LW (2016) Prediction of biopore-and matrix-dominated flow from X-ray CT-derived macropore network characteristics. Hydrol Earth Syst Sci 20(10):4017. doi:10.5194/hess-20-4017-2016

Niemela S (1983) Statistical evaluation of results from quantitative microbiological examinations. NCFA report no. 1, Nordic Committee in Food Analysis, Uppsala, Sweden

Nicosia LA, Rose JB, Stark L, Stewart MT (2001) A field study of virus removal in septic tank drainfields. J Environ Qual 30(6):1933-1939. doi:10.2134/jeq2001.1933 
Norgaard T, Moldrup P, Olsen P, Vendelboe AL, Iversen BV, Greve MH, Kjaer J, de Jonge LW (2012) Comparative mapping of soil physicalchemical and structural parameters at field scale to identify zones of enhanced leaching risk. J Environ Qual 42(1):271-283. doi:10.2134 /jeq2012.0105

Oliver DM, Heathwaite L, Haygarth PM, Clegg CD (2005) Transfer of to water from drained and undrained grassland after grazing. J Environ Qual 34(3):918-925. doi:10.2134/jeq2004.0327

Pang L (2009) Microbial removal rates in subsurface media estimated from published studies of field experiments and large intact soil cores. J Environ Qual 38(4):1531-1559. doi:10.2134/jeq2008.0379

Pang L, McLeod M, Aislabie J, Šimůnek J, Close M, Hector R (2008) Modeling transport of microbes in ten undisturbed soils under effluent irrigation. Vadose Zone J 7(1):97-111. doi:10.2136/vzj2007.0108

Pang XL, Lee B, Boroumand N, Leblanc B, Preiksaitis JK, Yu Ip CC (2004) Increased detection of rotavirus using a real time reverse transcription-polymerase chain reaction (RT-PCR) assay in stool specimens from children with diarrhea. J Med Virol 72(3):496501. doi:10.1002/jmv.20009

Pappas EA, Kanwar RS, Baker JL, Lorimor JC, Mickelson SK (2008) Fecal indicator bacteria in subsurface drain water following swine manure application. Trans ASABE 51(5):1567-1573. doi:10.13031 $/ 2013.25313$

Parashar D, Khalkar P, Arankalle VA (2011) Survival of hepatitis A and E viruses in soil samples. Clin Microbiol Infect 17(11):E1-E4. doi:10.1111/j.1469-0691.2011.03652.x

Patni NK, Toxopeus R, Tennant AD, Hore FR (1984) Bacterial quality of tile drainage water from manured and fertilized cropland. Water Res 18(2):127-132. doi:10.1016/0043-1354(84)90059-9

Peters K, Hjort M, Jensen LS, Magid J (2011) Carbon, nitrogen and phosphorus distribution in particle size-fractionated separated pig and cattle slurry. J Environ Qual 40(1):224-232. doi:10.2134 /jeq2010.0217

Pesaro F, Sorg I, Metzler A (1995) In situ inactivation of animal viruses and a coliphage in nonaerated liquid and semiliquid animal wastes. Appl Environ Microbiol 61(1):92-97

Pillai SD (2006) Bacteriophages as fecal indicator organisms. In: Goyal SM (Ed) Viruses in foods. Springer, New York, pp 205-222. doi:10.1007/0-387-29251-9 8

Pina S, Jofre J, Emerson SÜ, Purcell RH, Girones R (1998) Characterization of a strain of infectious hepatitis $\mathrm{E}$ virus isolated from sewage in an area where hepatitis E is not endemic. Appl Environ Microbiol 64(11):4485-4488

Pintó RM, Costafreda MI, Bosch A (2009) Risk assessment in shellfishborne outbreaks of hepatitis A. Appl Environ Microbiol 75(23): 7350-7355. doi:10.1128/AEM.01177-09

Plauborg F, Ullum M and Grant R (2003) Development of an automated sampling technique for estimation of pesticides concentrations in drainage flow. In: Del Re AAM, Capri E, Padovani L, Trevisan M (eds) Pesticide in air, plant, soil and water system. Proc. XII Symp. Pesticide Chem., Piacenza, Italy, 4-6 June 2003, pp 789-800

Pourcher A-M, Françoise P-B, Virginie F, Agnieszka G, Vasilica S, Gérard M (2007) Survival of faecal indicators and enteroviruses in soil after land-spreading of municipal sewage sludge. Appl Soil Ecol 35(3):473-479. doi:10.1016/j.apsoil.2006.10.005

Purcell RH, Emerson SU (2008) Hepatitis E: an emerging awareness of an old disease. J Hepatol 48(3):494-503. doi:10.1016/j. jhep.2007.12.008

R Core Team (2013) R: language and environment for statistical computing. R Foundation for Statistical Computing, Vienna, Austria. http://www.R-project.org. Accessed January 2017

Raphael RA, Sattar SA, Springthorpe VS (1985) Long-term survival of human rotavirus in raw and treated river water. Can J Microbiol 31(2):124-128. doi:10.1139/m85-024

Renou C, Moreau X, Pariente A, Cadranel JF, Maringe E, Morin T, Causse X, Payen JL, Izopet J, Nicand E, Bourliere M, Penaranda
G, Hardwigsen J, Gerolami R, Peron JM, Pavio N (2008) A national survey of acute hepatitis E in France. Aliment Pharmacol Ther 27(11):1086-1093. doi:10.1111/j.1365-2036.2008.03679.x

Reynolds KA, Mena KD, Gerba CP (2008) Risk of waterborne illness via drinking water in the United States. In: Whitacre D (ed) Reviews of environmental contamination and toxicology, vol 192. Springer, New York, pp 117-158. doi:10.1007/978-0-387-71724-1 4

Rosenbom AE, Olsen P, Plauborg F, Grant R, Juhler RK, Brüsch W, Kjær J (2015) Pesticide leaching through sandy and loamy fields: longterm lessons learnt from the Danish Pesticide Leaching Assessment Programme. Environ Pollut 201:75-90. doi:10.1016/j. envpol.2015.03.002

Royer I, Angers DA, Chantigny MH, Simard RR, Cluis D (2007) Dissolved organic carbon in runoff and tile-drain water under corn and forage fertilized with hog manure. J Environ Qual 36(3):855863. doi:10.2134/jeq2006.0355

Sair A, D'souza D, Jaykus L (2002) Human enteric viruses as causes of foodborne disease. Compr Rev Food Sci Food Saf 1(2):73-89. doi:10.1111/j.1541-4337.2002.tb00008.x

Schijven JF, Hassanizadeh SM (2000) Removal of viruses by soil passage: overview of modeling, processes, and parameters. Crit Rev Environ Sci Technol 30(1):49-127. doi:10.1080 $/ 10643380091184174$

Schijven JF, Hoogenboezem W, Hassanizadeh M, Peters JH (1999) Modeling removal of bacteriophages MS2 and PRD1 by dune recharge at Castricum, Netherlands. Water Resour Res 35(4):11011111. doi:10.1029/1998WR900108

Scott C, Geohring L, Walter M (1998) Water quality impacts of tile drains in shallow, sloping, structured soils as affected by manure application. Appl Eng Agric 14(6):599-603. doi:10.13031/2013.19428

Skraber S, Gassilloud B, Schwartzbrod L, Gantzer C (2004) Survival of infectious poliovirus- 1 in river water compared to the persistence of somatic coliphages, thermotolerant coliforms and poliovirus-1 genome. Water Res 38(12):2927-2933. doi:10.1016/j. watres.2004.03.041

Snowdon JA, Cliver DO, Hurst CJ (1989) Coliphages as indicators of human enteric viruses in groundwater. Crit Rev Environ Control 19(3):231-249. doi:10.1080/10643388909388366

Sobsey M, Khatib L, Hill V, Alocilja E, Pillai S (2001) Pathogens in animal wastes and the impacts of waste management practices on their survival, transport and fate. In: Rice JM, Caldwell DM, Humenik FJ (eds) Animal agriculture and the environment: National Center for Manure and Animal Waste Management White Papers. ASABE, St. Joseph, MI, pp 609-666. doi:10.13031 /2013.20268

USEPA (2003) National pollutant discharge elimination system permit regulation and effluent limitation guidelines and standards for concentrated animal feeding operations. USEPA, Washington, DC

Vaz-Moreira I, Egas C, Nunes OC, Manaia CM (2013) Bacterial diversity from the source to the tap: a comparative study based on 16S rRNA gene-DGGE and culture-dependent methods. FEMS Microbiol Ecol 83(2):361-374. doi:10.1111/1574-6941.12002

Vinten A, Lewis D, Fenlon D, Leach K, Howard R, Svoboda I, Ogden I (2002) Fate of Escherichia coli and Escherichia coli $\mathrm{O} 157$ in soils and drainage water following cattle slurry application at 3 sites in southern Scotland. Soil Use Manag 18(3):223-231. doi:10.1111 jj.1475-2743.2002.tb00243.x

Walshe GE, Pang L, Flury M, Close ME, Flintoft M (2010) Effects of pH, ionic strength, dissolved organic matter, and flow rate on the cotransport of MS2 bacteriophages with kaolinite in gravel aquifer media. Water Res 44(4):1255-1269. doi:10.1016/j. watres.2009.11.034

Wheeler RE (2010) lmPerm. The R project for statistical computing. http://www.r-project.org/. Accessed January 2017

Wohlsen TD (2011) Comparative evaluation of chromogenic agar CM1046 and mFC agar for detection of E. coli and thermotolerant 
coliform bacteria from water samples. Lett Appl Microbiol 53(2): 155-160. doi:10.1111/j.1472-765x.2011.03086.x

Wuton VC, Togo CA, Pletschke BI (2009) Suitability of total coliform $\beta$ D-galactosidase activity and CFU counts in monitoring faecal contamination of environmental water samples. Water SA 35:85-88. doi:10.4314/wsa.v35i1.76649
Yates MV, Yates S (1990) Modeling microbial transport in soil and groundwater. ASM News 54(6):324-327

Ziemer C, Bonner J, Cole D, Vinjé J, Constantini V, Goyal S, Gramer M, Mackie R, Meng X, Myers G (2010) Fate and transport of zoonotic, bacterial, viral, and parasitic pathogens during swine manure treatment, storage, and land application. J Anim Sci 88(13):E84-E94. doi:10.2527/jas.2009-2331 